\title{
Multi-Criteria Decision Analysis Coupled with GIS and Remote Sensing Techniques for Delineating Suitable Artificial Aquifer Recharge Sites in Tafilalet Plain (Morocco)
}

\author{
Aicha Ousrhire ${ }^{*}, 1$, Hassane Oulidi Jarar ${ }^{2}$, Abdessamad Ghafiri ${ }^{1}$ \\ ${ }^{1}$ Laboratory of geomatics applied to geosciences and the environment, Department of geology, Hassan II university, Casablanca, 20660, \\ Morocco \\ ${ }^{2}$ SGEO research team, Department of mathematics, computer science and geomatics, Hassania school of public works, Casablanca, \\ 20230, Morocco
}

\section{A R T I C L E I N F O}

Article history:

Received: 12 October, 2020

Accepted: 17 November, 2020

Online: 14 December, 2020

\section{Keywords:}

AHP

Artificial aquifer recharge

Aquifer depletion

GIS

Remote sensing

Tafilalet plain

Morocco

\begin{abstract}
A B S T R A C T
Despite that groundwater is an important and vital water resource, it is not well managed; depletion of aquifers around the world due to overexploitation is of serious concern especially in arid regions where the situation is much more alarming. Tafilalet plain in Morocco which belongs to this type of environment is certainly no exception and is viewing its groundwater disappearing. Artificial aquifer recharge (AAR) is found to be appropriate to such an urgent issue. Thus, the objective of this paper is the exploration of suitable sites to process Artificial aquifer recharge in Tafilalet plain by the joint use of remote sensing $(R S)$, geographic information systems (GIS), and the analytic hierarchy process (AHP) method. For doing so, eight parameters were considered as groundwater influencing parameters such as slope, soil, geology, land Cover/land Use, depth to the water table, aquifer transmissivity, electrical conductivity and drainage density. The laters were integrated and processed in a GIS, their thematic layers were created, and their relative weights were generated by The AHP method based on their significance in recharging the aquifer. Afterward, thematic layers were reclassified and assigned their weights, so the GIS overlay tool was used for inferring artificial groundwater recharge potential regions in the study area. $47 \%$ were identified as suitable while only $12 \%$ were identified as unsuitable. Such studies facilitate groundwater management for stakeholders and water managers because important decisions may be taken in a record time which will preserve water resources and prevent them from being in an alarming situation.
\end{abstract}

\section{Introduction}

Groundwater is a valuable natural resource and constitutes a significant freshwater reservoir as it accounts for $30 \%$ of the earth's freshwater while surface water accounts for just $0.3 \%[1$, $2]$. Besides, groundwater offers a multitude of benefits in different forms. In fact, groundwater meets the need for drinking water to relatively half of the world's population $[3,4]$ and around $38 \%$ of the world's irrigated lands are supplied by groundwater [5], not to mention its contribution to the industry sector and its paramount role for the environment. Nevertheless, there is growing evidence that groundwater is under threat of numerous difficulties such as climate change impacts, contamination, pollution in addition to depletion [6-10]. Actually, many aquifers throughout the world

"Corresponding Author: Aicha Ousrhire, Email: aicha.ousrhire@gmail.com suffer from groundwater depletion [11-17] and this situation is much more serious in arid regions since groundwater constitutes their main source of water supply. Mismanagement and namely over-exploitation are considered as its major cause alongside many other factors. In fact, rapid population growth, agricultural and industrial activities that require a considerable availability of water together with climatic conditions notably of arid environments consisting of high evapotranspiration rates, low precipitation, and low vegetation cover are placing greater pressure on limited aquifer resources which has led to their intensive extraction in many parts of the world [9, 12, 17-25]. Moreover, If this abstraction is greater than the natural groundwater recharge, it is referred to as an overdraft; so, groundwater levels will drop sharply over time, triggering depletion [8, 9, 14, 17, 25-30], which can make the situation complicated as the replenishment of the aquifers 
to the original levels takes a lot of time [3] and it is more complicated in cases of fossil or compacting aquifers because of their irreversible and non-renewable character $[14,31]$. In such a way, countless negative impacts and many political, social, environmental, and economic issues, such as conflicts, land subsidence, degradation of groundwater dependent ecosystems, deterioration of water quality, aquifers drying and obviously water scarcity will take place particularly in countries which are groundwater dependent [10,11, 14, 23-25, 27, 28, 32-39].

The above situation has been a major point of concern of water researchers, water managers, and water decision-makers, seeing that in many parts of the world a lot of measures have been taken to properly manage their groundwater resources and to prevent the worsening of the situation. The implementation of monitoring networks to control groundwater levels, the establishment of groundwater laws, and the setting up of exploitation rules for regulating its use, in addition to the organization of awarenessraising companies to urge on the importance of water and also education on water conservation are a good illustration of the undertaken measures $[9,37,38,40,41]$, but even so, the decline of groundwater resources levels has been noticed and is still ongoing in many places around the globe. This is especially due to the violations of the established rules and the intensive mining of underground water notably in case of droughts. Added to that, the natural recharge of aquifers by streams, precipitation, rivers, pond seepage, reservoirs, irrigation canals, and lakes has become overwhelmed by the intensity of groundwater withdrawals [25] and has become difficult to occur especially in urbanized areas [42], because the presence of impervious surfaces such as roads, sidewalks, driveways and parking lots has led to many modifications to natural processes like impeding the infiltration of water. Thereby, the natural recharge of aquifers has proved to be insufficient to fill the quantity of water coming out of the aquifers in many parts of the world. Given these trends, water researchers, water managers, and water decision-makers have been prompted to think about solutions and innovative scientific analyses in order to bring better and sound management strategies that may address this groundwater issue and guarantee its sustainable use. If decreasing discharge and regulating abstraction has not brought important results, then this depletion can only be alleviated by increasing and boosting recharge.

Thus, artificial or managed aquifer recharge is a promising solution to this problem. Actually, artificial aquifer recharge (AAR) or managed aquifer recharge (MAR) is defined as an intentional human intervention arranged to enhance groundwater resources through processes implemented to heighten and improve the replenishment of depleted aquifers or depleting aquifers [22, 43-47]. The (AAR) has many gains and benefits, the major ones are the restoration of groundwater balance and the revival of the overexploited aquifers [11, 19, 25, 39, 48, 49], the other ones are enhancement and raising the water table which will cut down its operating costs, improving groundwater quality and prevention of seawater intrusion in the case of coastal aquifers [28, 46, 49, 50], alleviating floods adverse impacts given that during strong storms aquifers can be managed to play the role of a water storage reservoir which will mitigate the magnitude of flooding [22, 45, 51-53], besides (AAR) can limit the loss of land covered with surface water storage structures and limit the loss of water by evaporation in dams, ponds, and other surface reservoirs by storing www.astesj.com it in aquifers $[12,39]$. In order to artificially recharge aquifers, treated wastewater, floodwater, or water pumped from another aquifer can be used and redirected across the land surface. So, a variety of ways and systems have been developed such as infiltration basins, canals, ponds, ditches, sprinkler systems, rills, and irrigation furrows where the surface water is put on and subsequently infiltrates into the soil and moves downward to recharge aquifers or simply artificial recharge can be achieved by injecting water directly into the aquifer through injection wells especially in case of confined aquifers and each of these ways is implemented according to specific conditions. Applying the (AAR) needs some criteria to be met notably, the presence of highly permeable geological formations allowing percolation of recharge water, endowed with high capacity of water storage (unsaturated zone thickness should be deep enough to increase the piezometric level) and have high transmissivity. Moreover, the presence of a water source ensuring volumes of water needed for the recharge such as dams, stormwater runoff, wastewater treatment station, and desalination station besides, the water intended for artificial groundwater recharge as well as those of receiving aquifer must be of good quality and meet a certain number of standards and also good knowledge of the climatic characteristics of the region is essential in (AAR) projects (temperature, evaporation, rainfall, frequency of floods, periods of drought, snowmelt, etc.). Consequently, performing the (AAR) requires a suitable place whose selection depends on solid scientific analysis. Actually, selecting optimal sites for (AAR) involves integrating several parameters proved to have an influence on the infiltration of water to aquifers. To do this, a combination of geospatial technologies and multi-criteria decision analysis (MCDA) is used in this study.

Tafilalet plain was chosen as the study area in the present study as it is one of the Moroccan regions calling for urgent intervention and requiring important measures to be taken at all levels, including the environmental one; it suffers from enormous environmental difficulties mainly scarcity and poor water quality, due essentially to long periods of drought that has affected the region in recent years, combined to severe nature of the climate which makes groundwater resources the main source of water supply in low-flow periods. In 1967, the Hassan Addakhil dam was constructed in the north of Errachidia city and located at a distance of about $80 \mathrm{~km}$ from the Tafilalet plain, it was built on wadi Ziz in order to regulate floodwaters and, simultaneously, it serves a variety of goals, ranging from irrigation to water supply for domestic and industrial uses and remarkably it helps to establish a certain balance of groundwater of Tafilalet aquifer both quantitatively and qualitatively, but in front of considerable population growth and an agrarian-based economy resulting in increasing the number of wells notably prived ones, the exploitation of groundwater resources is proceeding at a very fast pace which has lead to their overdraft, so the implementation of artificial aquifer recharge in this region is essential to recover its overexploited groundwater.

Thus, the prime focus of the current paper is to delineate the artificial groundwater recharge potential regions in Tafilalet plain (Morocco), using the analytic hierarchy process (AHP) method which is a forme of Multiple-criteria decision analysis (MCDA) and geospatial technologies represented here by remote sensing (RS) and geographic information systems (GIS). 

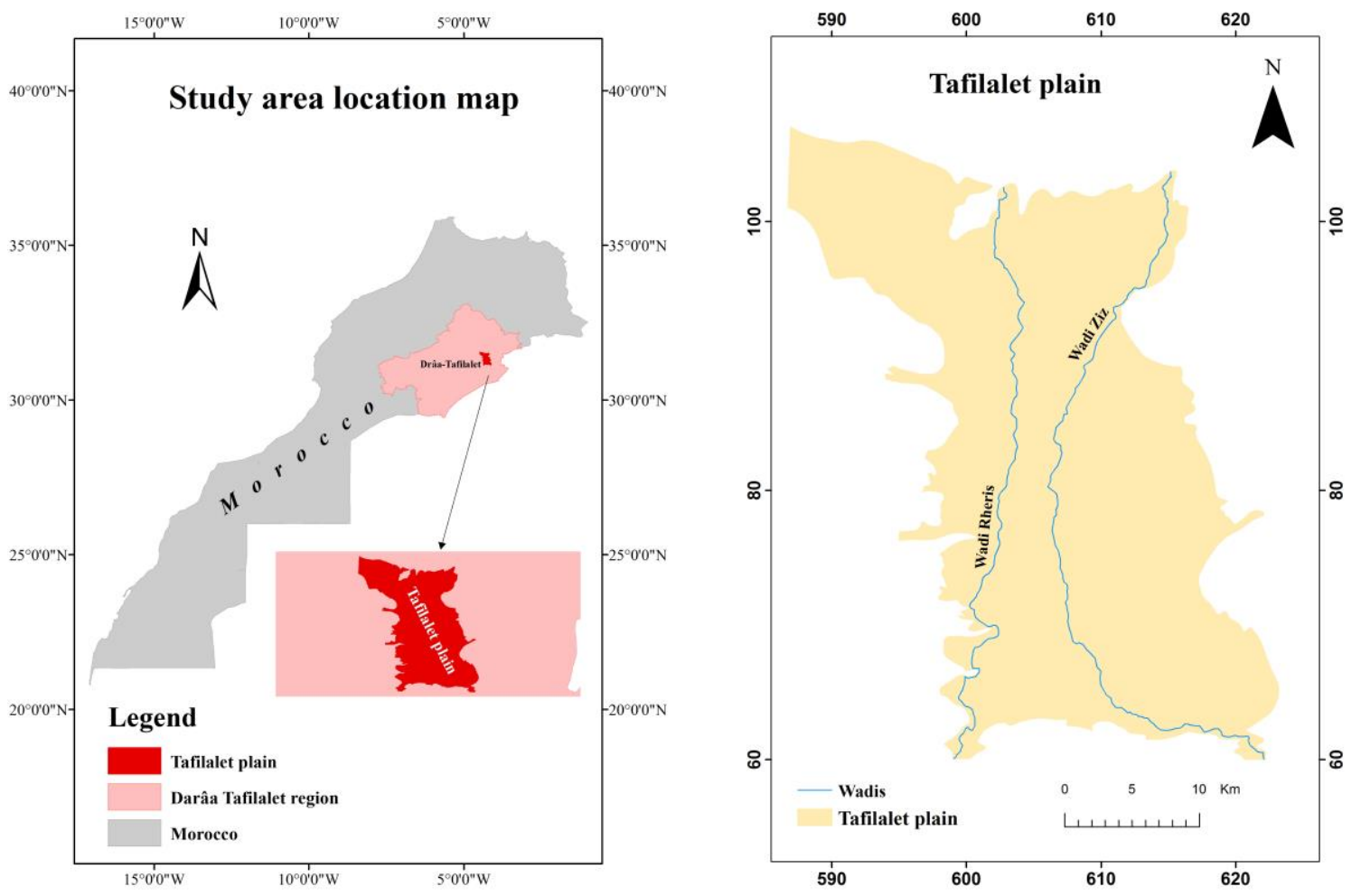

Figure 1: Study area location map

After this introduction, the following parts are organized in five sections, the first one is an overview of the study area, the second one is a presentation of the materials and definition of the methods used, the third one is a description of the major results, the fourth one is a discussion about the outcomes and the last one is a conclusion of the main ideas of this study.

\section{Study Area}

Tafilalet plain belongs to the pre-Saharan region located in the extreme southeast of the kingdom of Morocco, particularly in the Drâa-Tafilalet region, at an altitude of 700 to $800 \mathrm{~m}$, it lies in between the coordinates of projection system Lambert zone Morocco (Zone I) $\mathrm{X}=580000 \mathrm{~m}$ to $\mathrm{X}=630000 \mathrm{~m}$ and $\mathrm{Y}=50000$ $\mathrm{m}$ to $\mathrm{Y}=120000 \mathrm{~m}$ (Figure 1), covers an area of about $700 \mathrm{~km}^{2}$, and the majority of its population are rural. Besides, Tafilalet plain is part of the quaternary basin of Tafilalet; it is an erosional depression arising out of the secondary and tertiary coverage clearing during the quaternary era, the bottom of this depression was, afterward, covered by the alluvium of wadis $\mathrm{Ziz}$ and Rheris. In fact, it constitutes the zone of gathering and accumulation of alluvial deposits, conveyed by surges of the Ziz and Rheris wadis and their tributaries. Moreover, Tafilalet plain extends over three different geological formations, it is enclosed by the High Atlas in the north, it crosses the pre-Africain furrow and is surrounded at the south by the old massif of the Anti-Atlas domain as well as overlying an impermeable Palaeozoic and pre-Cambrian substratum.

Concerning the climate, Tafilalet plain is dominated by an arid to semi-arid climate, typified by a great rainfall scarcity as the average annual precipitation barely reaches $70 \mathrm{~mm}$ all over the area, this is mainly due to the presence of Atlas reliefs in the north which constitute a barrier to oceanic influences. The climate is also characterized by a great irregularity of the temperature, rising to very high values in summer (about 40 degree $\mathrm{C}^{\circ}$ especially in July) and dropping to very low values in winter (surroundings 0 degree $\mathrm{C}^{\circ}$ especially in January), this great difference in temperature brings out two seasons: a hot season from May to October and a cold season from November to April so, in the Tafilalet plain, The dry periods last almost all the year with extremely hot summers and highly cold winters which is mainly due to its openness on the Sahara. In addition, The mean annual evapotranspiration is close to $500 \mathrm{~mm}$ which is higher than the mean annual rainfall, this means that Tafilalet plain suffers from water deficit all over the year. Adding to that, the dominant winds are commonly known as Chergui, they are characterized by their hotness and dryness and they blow from the southeast to the northeast.

Regarding the water resources, Tafilalet plain is, on the one hand, underlain by confined and unconfined aquifers, the north of the region encloses the infra Cenomanian aquifer which is a totally confined aquifer, whereas the entire area is almost occupied by an unconfined, shallow and very extensive aquifer named as "Tafilalet aquifer" which is the aquifer targeted in this study. In fact, this aquifer is not very thick and the water below the ground surface is $2 \mathrm{~m}$ to more than $30 \mathrm{~m}$ in some places, its shape matches the slightly convex shape of the plain and its slope is very weak. Consequently, this makes the water of this aquifer sensitive to hydrological and atmospheric conditions such as pollution and evapotranspiration. The spatial distribution of Tafilalet aquifer transmissivities indicates dispersed values ranging from $10^{-2} \mathrm{~m}^{2} / \mathrm{s}$ 
to $10^{-4} \mathrm{~m}^{2} / \mathrm{s}$ and groundwater flows mainly from the north-east to south-west, south, and south-east characterized by an average hydraulic gradient that declines from upstream to downstream [54]. From a lithological point of view, the base of the aquifer is constituted by conglomerates and lacustrine limestones including gravelly levels and at the top of the aquifer, there are sands, gravel, and pebbles, covered with unevenly distributed powerful silts. Moreover, the main sources of groundwater recharge of the Tafilalet aquifer are essentially from the High Atlas mountains surrounding the plain in the north, from surface runoff including rivers, mainly Ziz and Rheris wadis, as well as irrigation water which infiltrates to the aquifer, and without forgetting precipitation and dams contribution. Conversely, the Tafilalet aquifer discharges mostly by evapotranspiration, by extraction from wells, and by Khettarats and springs. On the other hand, Tafilalet plain is crossed by many ephemeral wadis, the major ones are wadi $\mathrm{Ziz}$ in the center, wadi Rheris in the west. Besides, the region holds some springs resulting from the emergence of groundwater resources to the surface, such as Aïn Dolla-Attrouss and Aïn Chorfa.

Furthermore, the heart of the Tafilalet plain is made up of a very large palm grove, which occupies most of its surface so, a great part of the plain is devoted to agriculture, especially irrigated agriculture, making it the main economic activity in this region and is the main source of income for a large population. Because of climate aridity, the majority of crops are water-demanding which implies a strong mobilization of water notably during the months of June and July and due to the scarcity of surface waters in the region, growers are turning to groundwater exploitation to fill this water gap and meet their water needs. This has made the groundwater balance in aquifers of Tafilalet plain quickly in deficit.

\section{Materials and Methods}

The overall process followed in this study of the artificial aquifer recharge site selection has been schematically presented in (Figure 2).

\subsection{Influencing factors Selection reason}

The prediction of suitable sites for artificial aquifer recharge depends on a number of parameters that have an influence in either a direct or indirect way on the process of aquifer recharge. The selection of these factors was based firstly on a deep review of studies of artificial recharge carried out in other areas in the world, secondly on a complete understanding of the characteristics and specificity of the study area "Tafilalet Plain" and thirdly on the point of view of experts. Thus, eight factors were revealed to have control over the recharge of the Tafilalet aquifer, including slope, soil, geology, land cover/ land use, depth to the water table, aquifer transmissivity, electrical conductivity and drainage density as mentioned in (Table 1).

- Slope: The slope is one of the essential factors influencing the artificial aquifer recharge because the slope directly affects the penetration of water into the soil. Actually, the flatter the ground, the more time the water has to sink in, unlike the steep slopes where the water runs over the ground rather than entering it [25, 55-57]. However, the penetration of water is not guaranteed even if the slope is suitable because it depends on the soil's nature.
- Soil: Soil is a factor of significant importance in aquifer recharge because soil's nature determines the percolation ability of the soil as well as the water infiltration quantity and eventually governs the recharging capacity of the bedrock [58]. Moreover, soil acts as a purificator of water [29] that is why it should contain high rates of loam and sand to avoid groundwater contamination and to ensure a high infiltration rate.

- Geology: Taking into consideration geology in artificial aquifer recharge site selection is of major importance because geological formations which must be selected should enjoy high permeability so that water can flow seamlessly downward towards the groundwater besides, they should have adequate transmissivity and high water storage capacity.

- Depth to the water table: Depth to the water table or unsaturated zone thickness is the distance from the ground surface to the groundwater, it is another major factor to consider in artificial groundwater recharge site selection since, the deeper the water table, the greater the amount of groundwater storage, and the more efficient the artificial aquifer recharge will be Moreover, the deeper the water table, the more purified the water will be, because it will pass through a very large layer of soil, which is called soil aquifer treatment (SAT) [19, 29]. Acceptable depth is about $3 \mathrm{~m}$ consequently, sites, where the depth is less than $3 \mathrm{~m}$, should not be considered [59].

- Transmissivity: transmissivity is an important hydrodynamic parameter of an aquifer which makes its consideration paramount in the selection of suitable sites for artificial groundwater recharge. Actually, transmissivity determines the rate of water flowing per unit width of the fully saturated thickness of an aquifer under a unit hydraulic gradient [25, 60-62] so, to avoid the excessive formation of groundwater mounds that interfere with the infiltration process, aquifers should be unconfined and sufficiently transmissive to allow the lateral flow of infiltrated water well away from the recharge zone [49].

- Drainage density: Drainage density is defined as the total length of streams of all orders per unit area and provides an indication of the watershed draining state. Drainage density was heeded as another factor of artificial aquifer recharge site selection because it indirectly signals the suitability of a site. In fact, high drainage density allows less penetration and more surface runoff and areas with great infiltration capacity are endowed with low drainage density [25, 39, 51, 58, 63-68] hence appropriate to artificial aquifer recharge.

- Electrical Conductivity: Groundwater quality is a paramount parameter that should be investigated in the artificial aquifer recharge projects because it is a determinant factor of the future usage of that water. Usually, the water intended for artificial aquifer recharge is of good quality but when it penetrates across a geological formation and mingles with different dissolved materials in it, its quality may get altered. Electrical conductivity (EC) is considered in this study because its variations have similar trends to those of total dissolved solids (TDS) as shown in the following formula :

$$
\mathrm{EC}=T D S / 0.65
$$


In fact, the higher the electrical conductivity, the poorer the water quality and vice versa [69]. Thus, the quality of groundwater will be assessed through the EC in the artificial aquifer recharge site selection.

- Land Cover / Land Use (LCLU) : (LCLU) is one of the important aquifer recharge influencing factors, it affects both the infiltration capacity and the water restraining of the land. Actually, areas with an important density of vegetation cover are appropriate for undertaking artificial aquifer recharge projects because the denser the vegetation cover, the more the runoff is slowed down and the more water infiltration takes place and also the less evapotranspiration and soil surface erosion will occur. In addition, organisms present in the soil and plant roots form openings in the subsoil, allowing water to infiltrate easily, unlike in areas without vegetation and in built-up areas, where the soil is mostly impervious, which favors runoff and prevents infiltration.

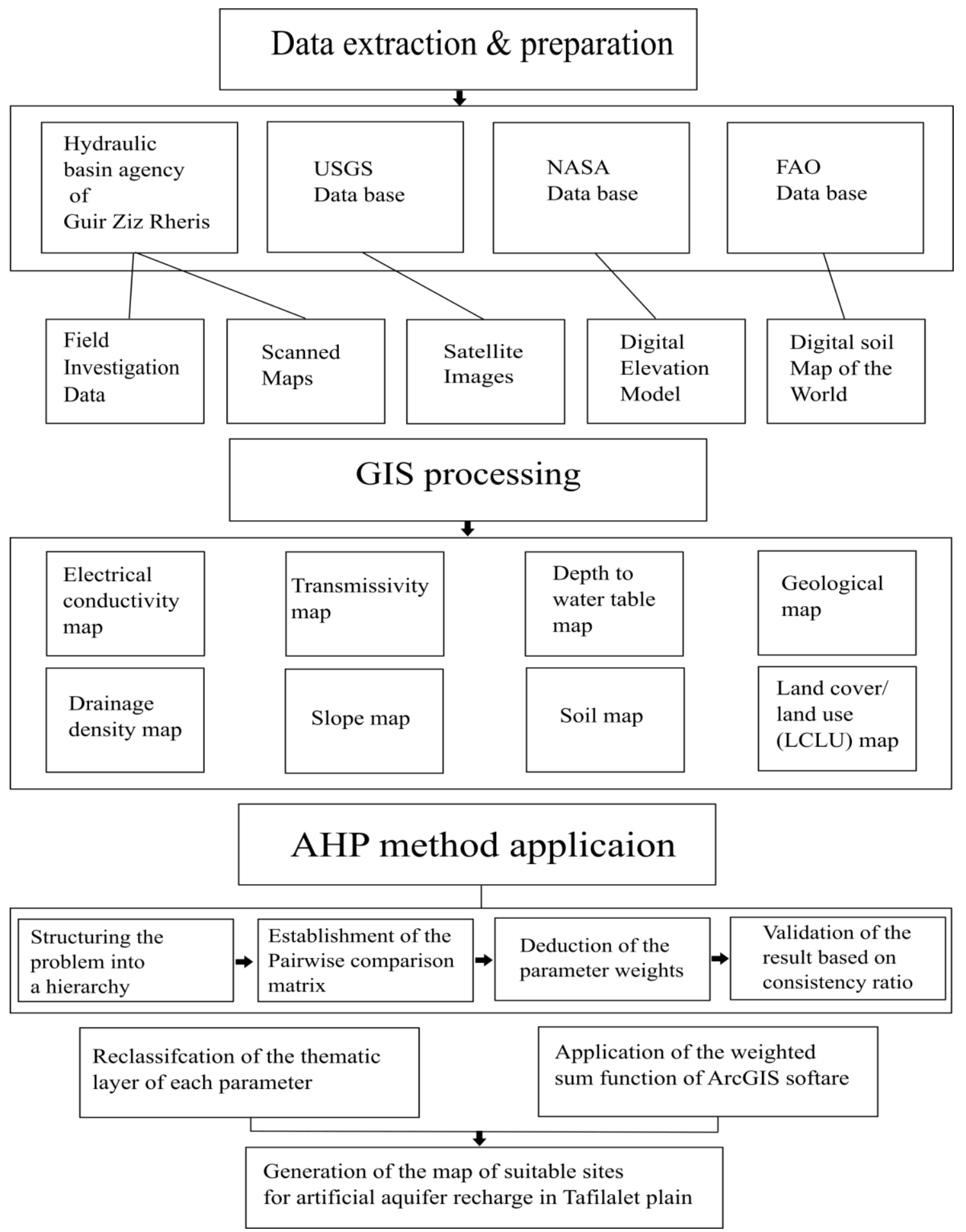

Figure 2: Methodology workflow 
Table 1: Data Extraction and Preparation

\begin{tabular}{|c|c|c|c|c|}
\hline Data & Origin format & Data source & Acquisition mode & Output \\
\hline Slope & $\begin{array}{l}\text { ASTER DEM at } \\
30 \mathrm{~m}\end{array}$ & $\begin{array}{l}\text { National Aeronautics and space } \\
\text { administration (NASA) website }\end{array}$ & Extraction & $\begin{array}{l}\text { Slope map of } \\
\text { Tafilalet plain }\end{array}$ \\
\hline Soil & $\begin{array}{l}\text { Digital soil map } \\
\text { of the world }\end{array}$ & $\begin{array}{l}\text { Food and Agriculture Organization } \\
\text { of the United Nations (FAO) } \\
\text { website }\end{array}$ & Extraction & $\begin{array}{l}\text { Soil map of } \\
\text { Tafilalet plain }\end{array}$ \\
\hline $\begin{array}{l}\text { Geological } \\
\text { data }\end{array}$ & $\begin{array}{l}\text { geological map } \\
\text { of Tafilalet- } \\
\text { Taouz }(1 / 200000 \\
\text { scale }) \\
\end{array}$ & $\begin{array}{l}\text { Hydraulic basin agency of Guir Ziz } \\
\text { Rheris }\end{array}$ & Digitalization & $\begin{array}{l}\text { Geological map of } \\
\text { Tafilalet plain }\end{array}$ \\
\hline $\begin{array}{l}\text { land } \\
\text { Cover/land } \\
\text { Use (LCLU) }\end{array}$ & $\begin{array}{l}\text { satellite image } \\
\text { (Landsat 8) }\end{array}$ & $\begin{array}{l}\text { United states geological survey } \\
\text { (USGS) institute website }\end{array}$ & Classification & $\begin{array}{l}\text { LCLU map of } \\
\text { Tafilalet plain }\end{array}$ \\
\hline $\begin{array}{l}\text { Depth to the } \\
\text { water table }\end{array}$ & $\begin{array}{l}\text { Excel sheet of } \\
\text { field } \\
\text { investigation } \\
\text { data }\end{array}$ & $\begin{array}{l}\text { hydraulic basin agency of Guir Ziz } \\
\text { Rheris }\end{array}$ & Interpolation & $\begin{array}{l}\text { Depth to the water } \\
\text { table map of } \\
\text { Tafilalet aquifer }\end{array}$ \\
\hline Transmissivity & $\begin{array}{l}\text { Excel sheet of } \\
\text { field } \\
\text { investigation } \\
\text { data }\end{array}$ & $\begin{array}{l}\text { hydraulic basin agency of Guir Ziz } \\
\text { Rheris }\end{array}$ & Interpolation & $\begin{array}{l}\text { Transmissivity } \\
\text { map of Tafilalet } \\
\text { aquifer }\end{array}$ \\
\hline $\begin{array}{l}\text { Electrical } \\
\text { conductivity }\end{array}$ & $\begin{array}{l}\text { Excel sheet of } \\
\text { field } \\
\text { investigation } \\
\text { data }\end{array}$ & $\begin{array}{l}\text { hydraulic basin agency of Guir Ziz } \\
\text { Rheris }\end{array}$ & Interpolation & $\begin{array}{l}\text { Electrical } \\
\text { conductivity map } \\
\text { of Tafilalet } \\
\text { aquifer }\end{array}$ \\
\hline $\begin{array}{l}\text { Drainage } \\
\text { density }\end{array}$ & $\begin{array}{l}\text { ASTER DEM at } \\
30 \mathrm{~m}\end{array}$ & $\begin{array}{l}\text { National Aeronautics and space } \\
\text { administration (NASA) website }\end{array}$ & $\begin{array}{l}\text { Extraction of the } \\
\text { hydrographic network } \\
\text { then application of Line } \\
\text { Density }\end{array}$ & $\begin{array}{l}\text { Drainage density } \\
\text { map of Tafilalet } \\
\text { plain }\end{array}$ \\
\hline
\end{tabular}

\subsection{Data extraction, preparation, and GIS processing:}

Given the interdisciplinary nature of groundwater, using remote sensing (RS) and geographic information systems (GIS) techniques are required because RS is a technology that provides important and information-rich geospatial data, especially for unreachable and very large areas. Moreover, GIS is commonly known for its usefulness to handle, analyze, integrate, and process various thematic geospatial data.

Therefore, in order to get the geographic data related to the above-mentioned factors, various data sources were used: FAO database, NASA database, USGS database, and other data were given by the hydraulic basin agency of Guir-Ziz-Rheris as detailed in Table 1. Furthermore, in order to process and to analyze those data, the geographic data processing functions of the ArcGIS software were used. In fact, as indicated in Table 1, slope and hydrographic network were extracted from ASTER DEM at $30 \mathrm{~m}$, then the drainage density was formed by applying the Line Density function to the hydrographic network, the soil was extracted from the digital soil map of the world taken from the FAO database, geology was digitized from the geological map of Tafilalet-Taouz (1/200000 scale), electrical conductivity, transmissivity and depth to the water table were taken from field surveys carried out with the hydraulic basin agency of Guir-Ziz-Rheris and land cover/land use (LCLU) was classified from satellite image (Landsat 8) drawn from USGS database. Thus, a geospatial database was constructed and filled with the aforementioned data. Afterward, using ArcGIS software a thematic layer of each factor was created (Figure 3) and each thematic layer has been converted to raster format and reclassified into five classes pertaining to its importance for artificial groundwater recharge (Figure 4), each class is translated to a category and each category has assigned a score as it is detailed in Table 2. Actually, the five categories adopted are very good, good, moderate, poor, and very poor in accordance with a specific evaluation scale (Table 3 ).

\subsection{AHP method application}

After reclassification of all the thematic layers, appropriate weights were generated by the analytic hierarchy process method (AHP).

Indeed, AHP is a multi-criteria decision analysis method and a mathematically-based technique [70], the mathematical underpinnings and the philosophy of which were developed in the seventies of the last century by the mathematician Thomas L. Saaty [71], AHP involves breaking down a convoluted multi-criteria decision problem into a hierarchy also called decision modeling in order to organize and better understand the problem and analyze the decision to be made. 
a) Slope map

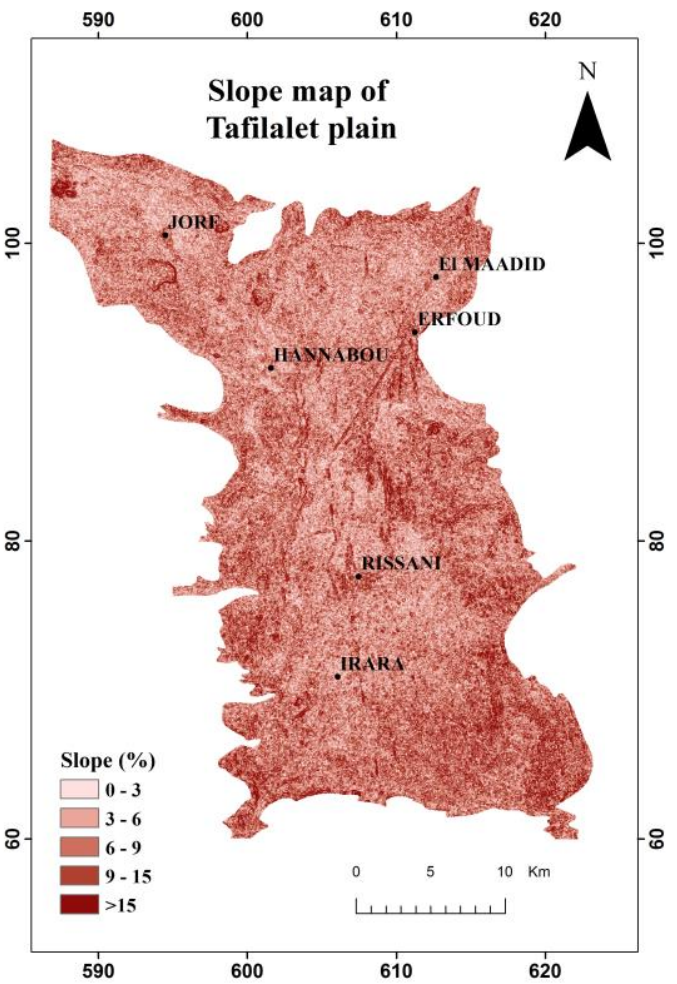

c) Geological map

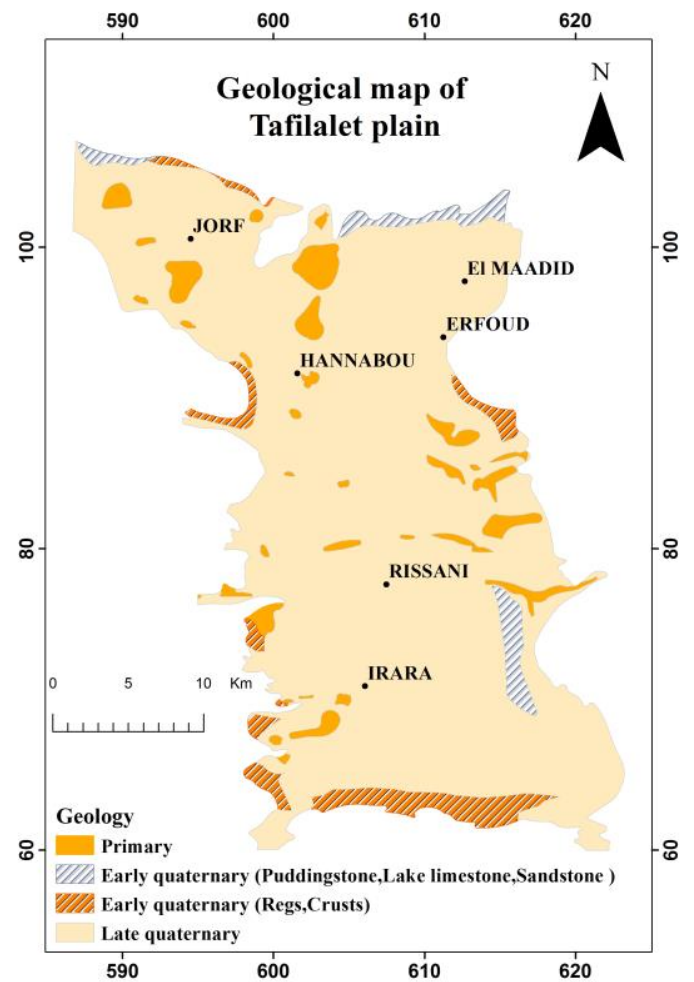

b) Soil map

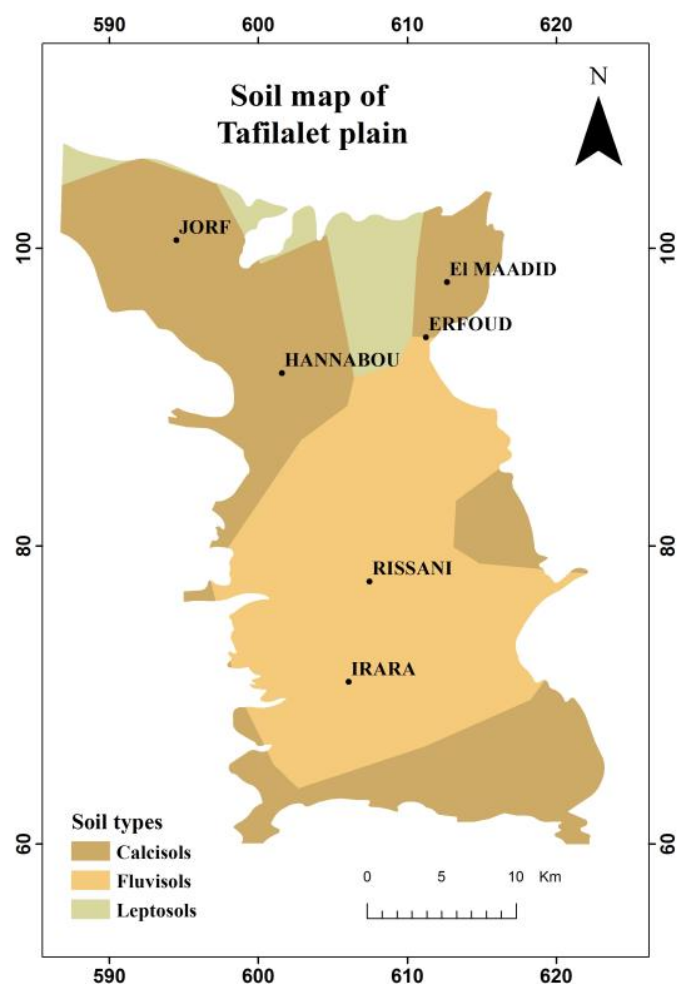

d) LCLU map

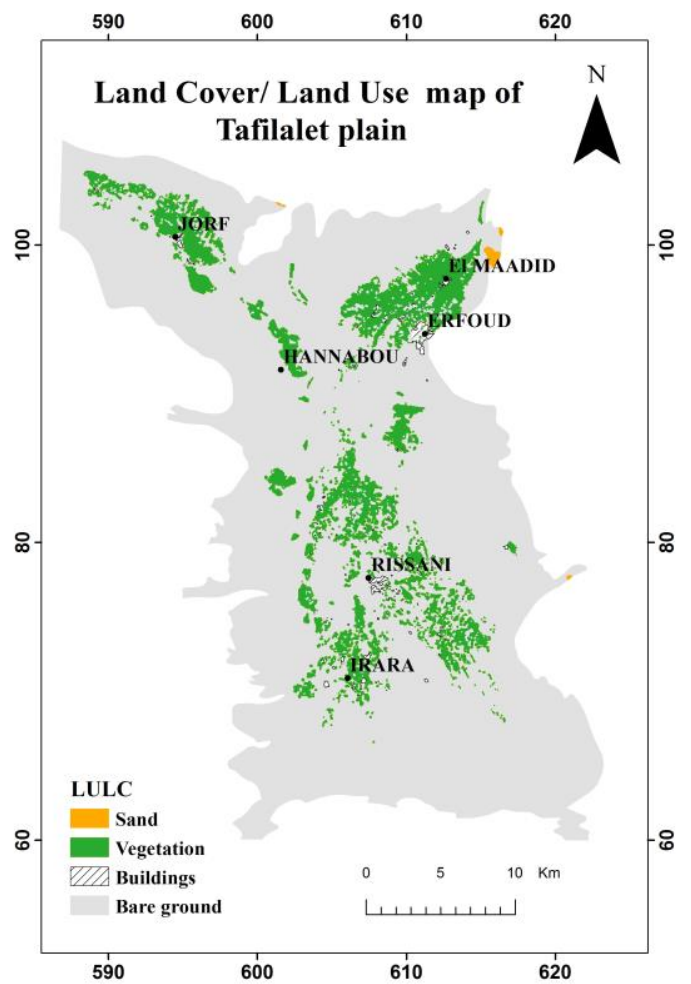

Figure 3: Thematic maps 
e) Depth to the water table map

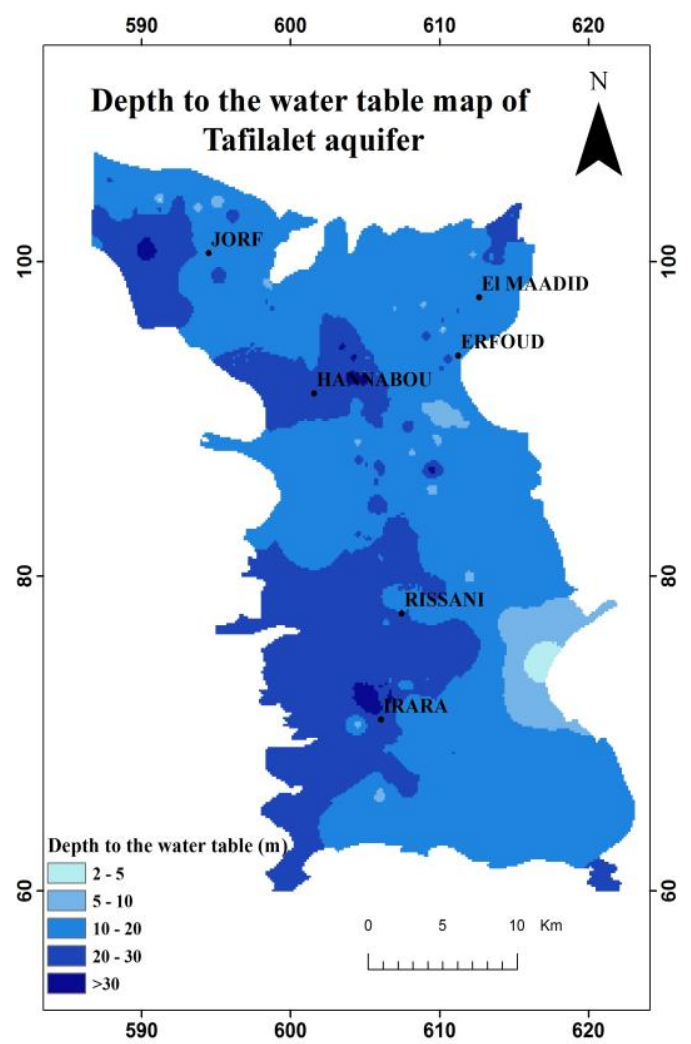

g) Electrical Conductivity map

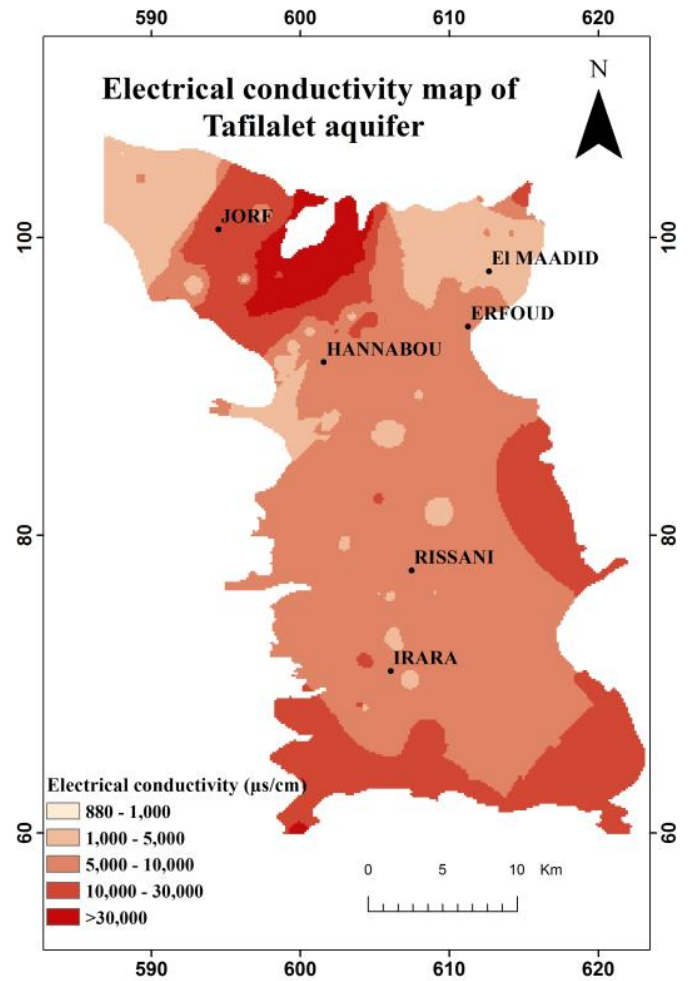

f) Transmissivity map

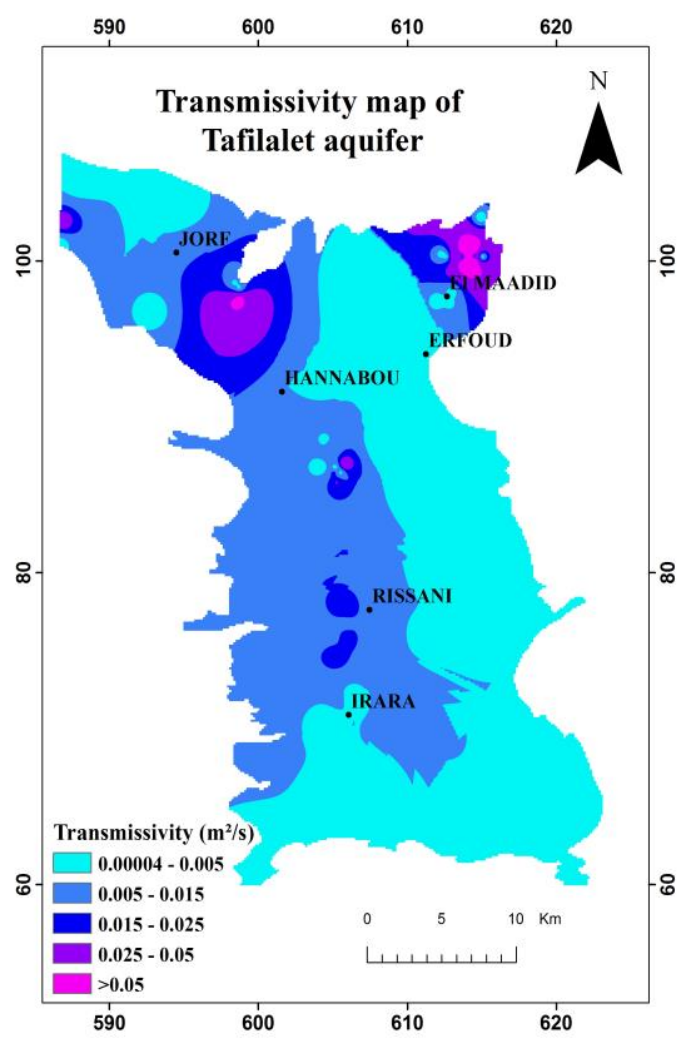

h) Drainage Density map

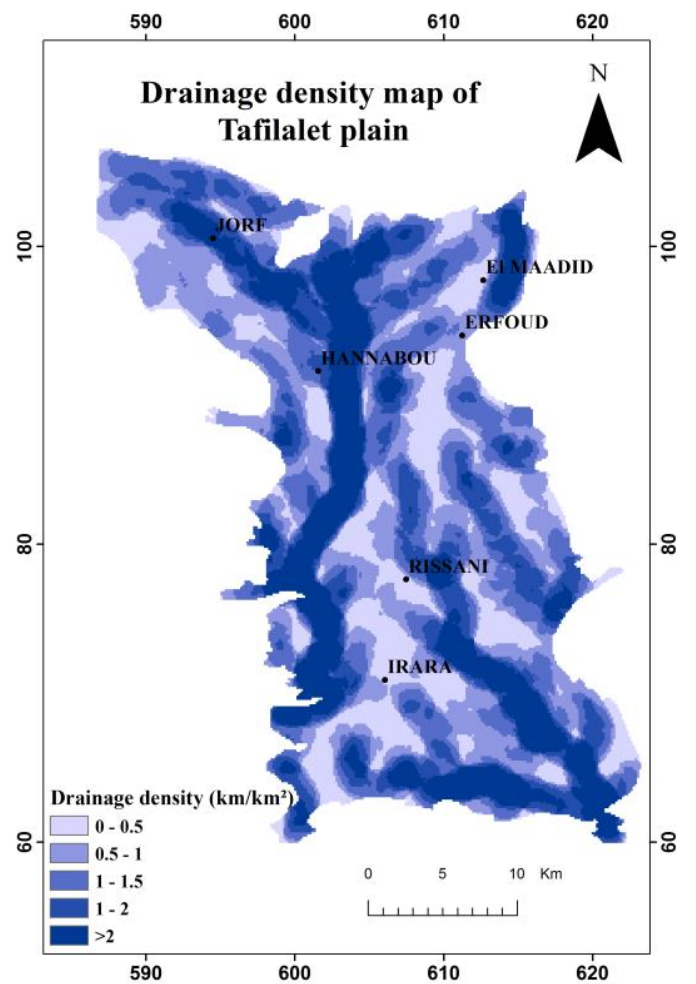

Figure 3: (Continued) 
a) Classified Slope map

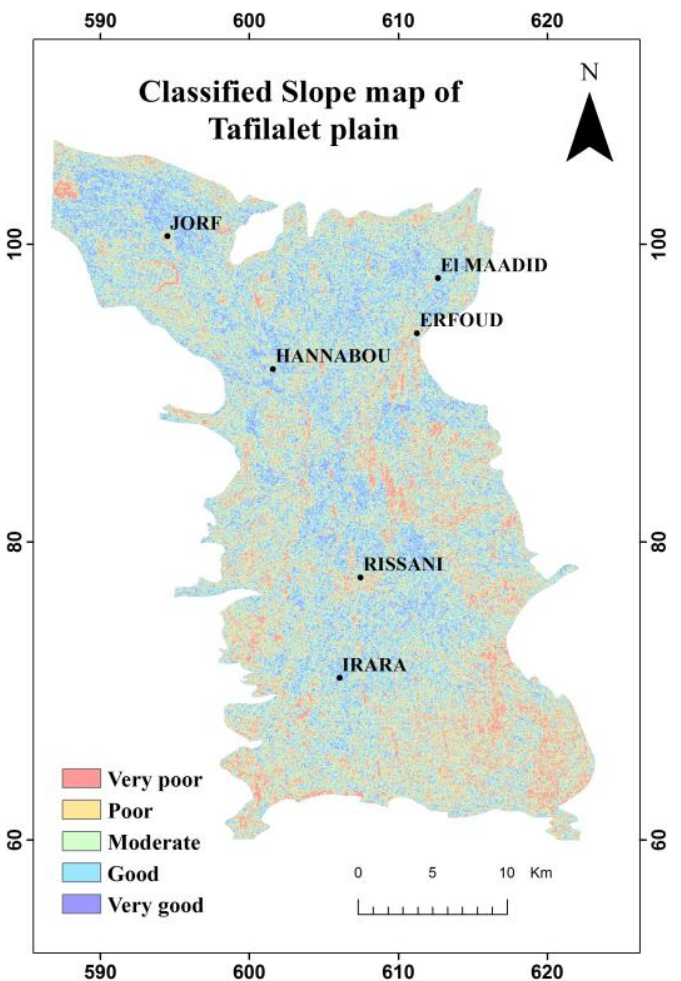

c) Classified Geological map

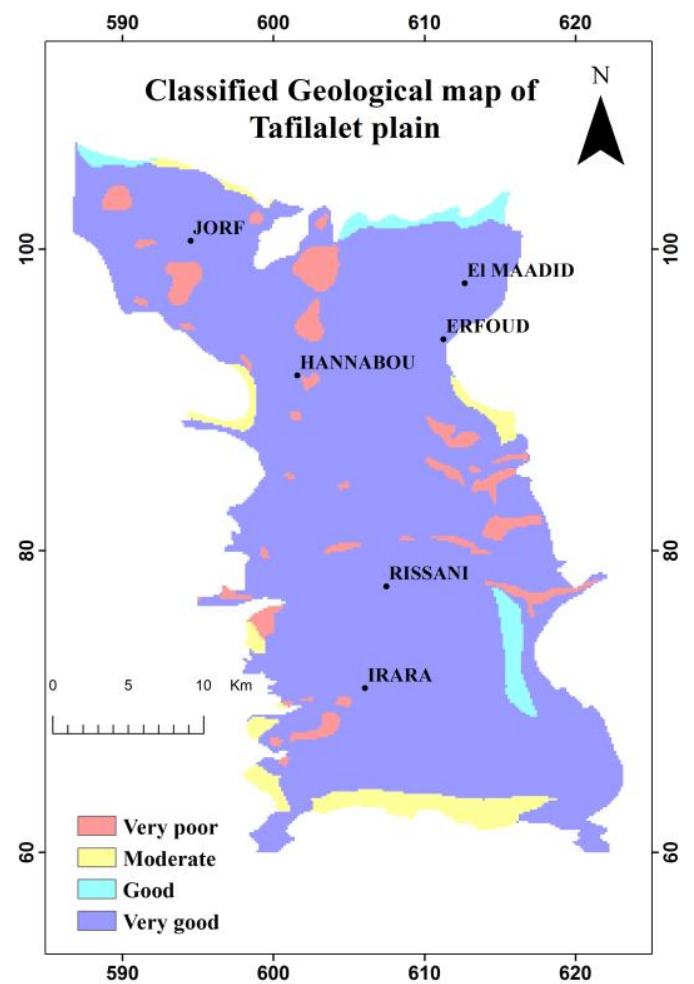

b) Classified Soil map

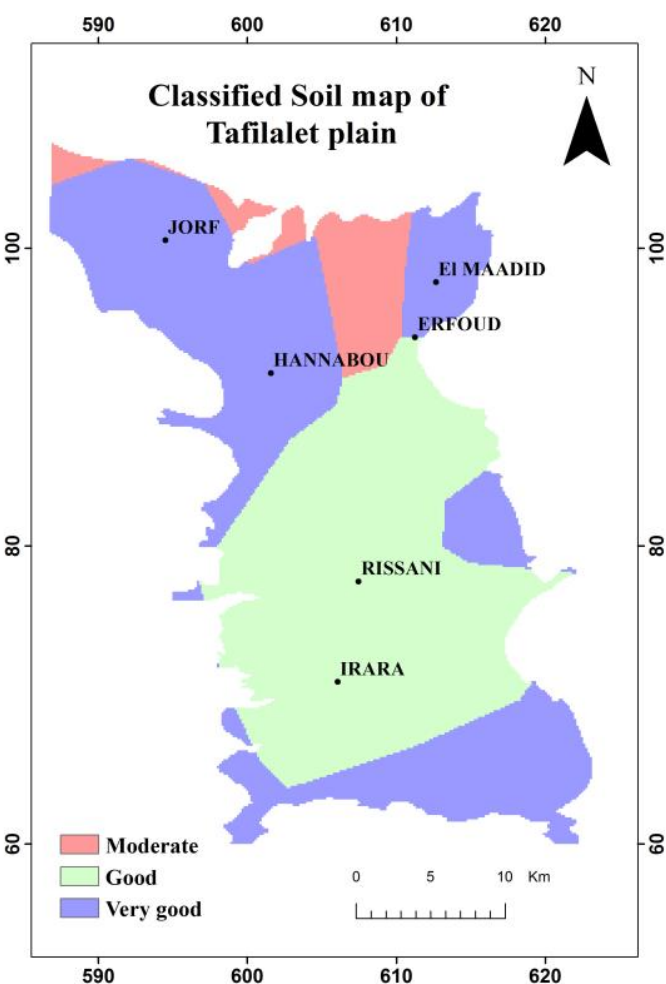

d) Classified LCLU map

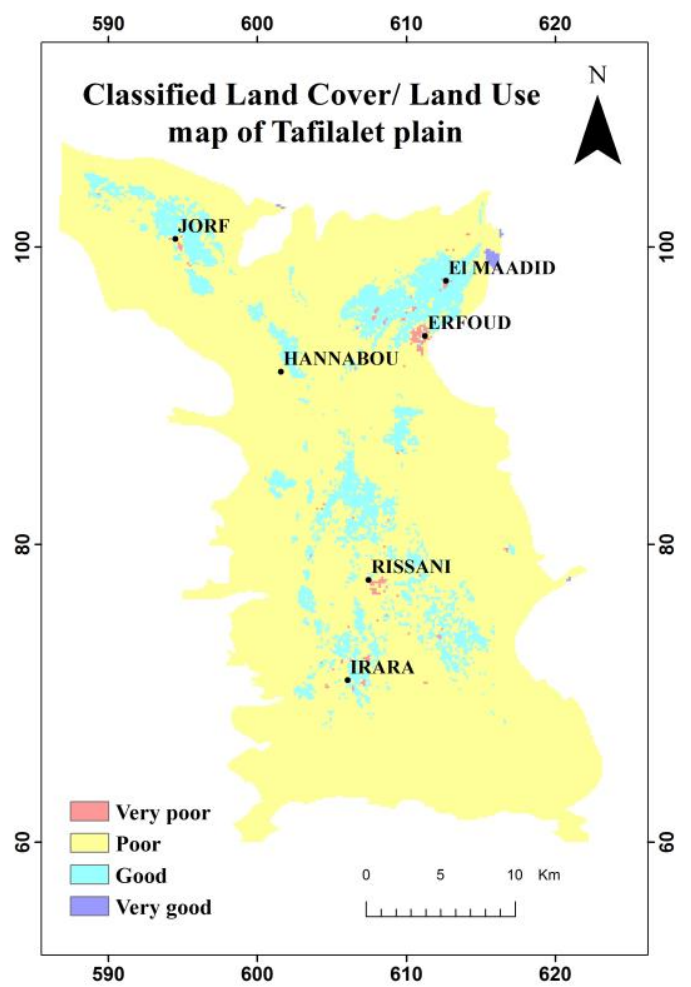

Figure 4: Classified thematic maps 
e) Classified Depth to the water table map

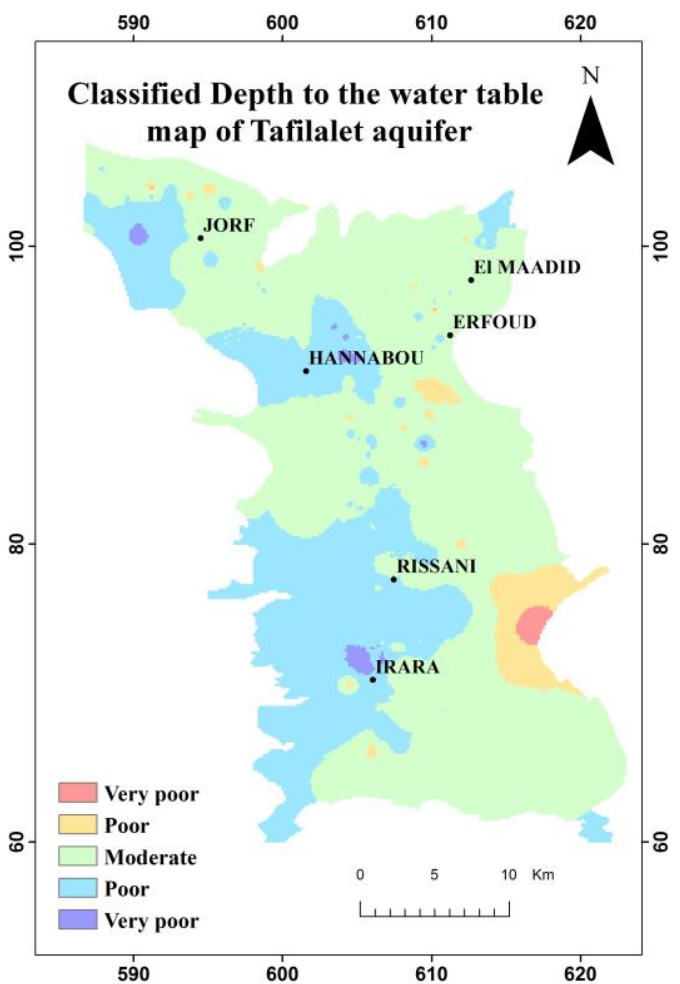

g) Classified Electrical Conductivity map

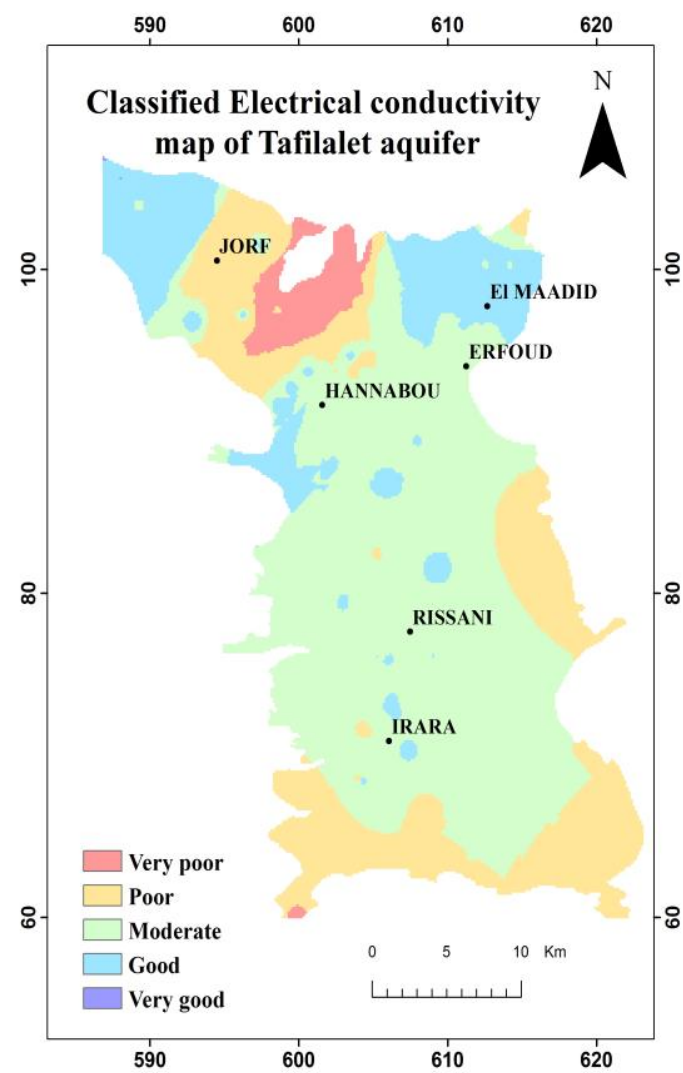

f) Classified Transmissivity map

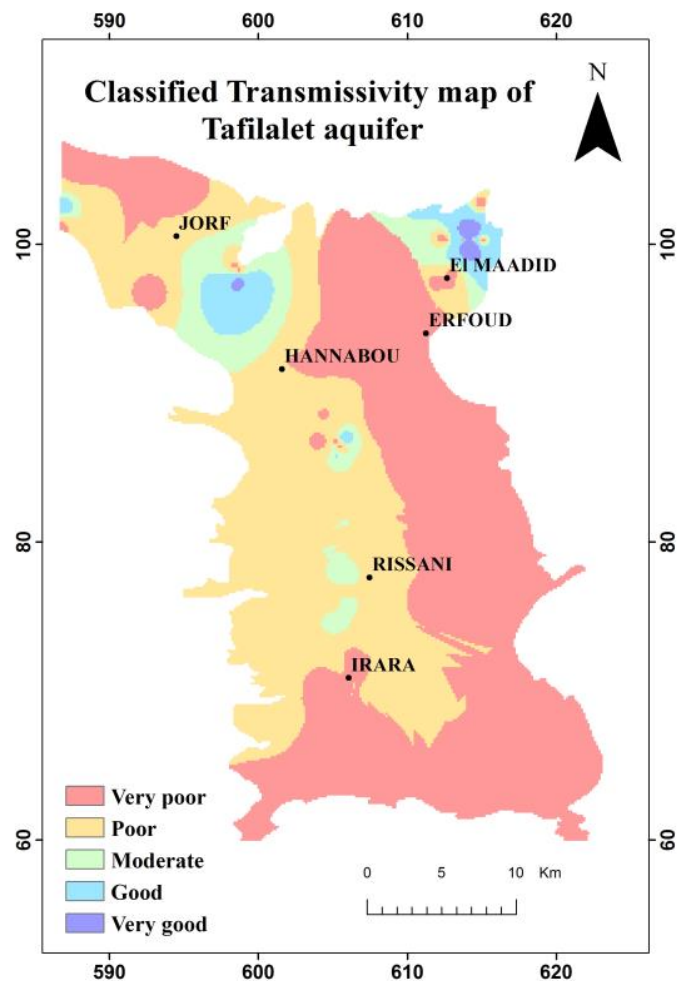

h) Classified Drainage Density map

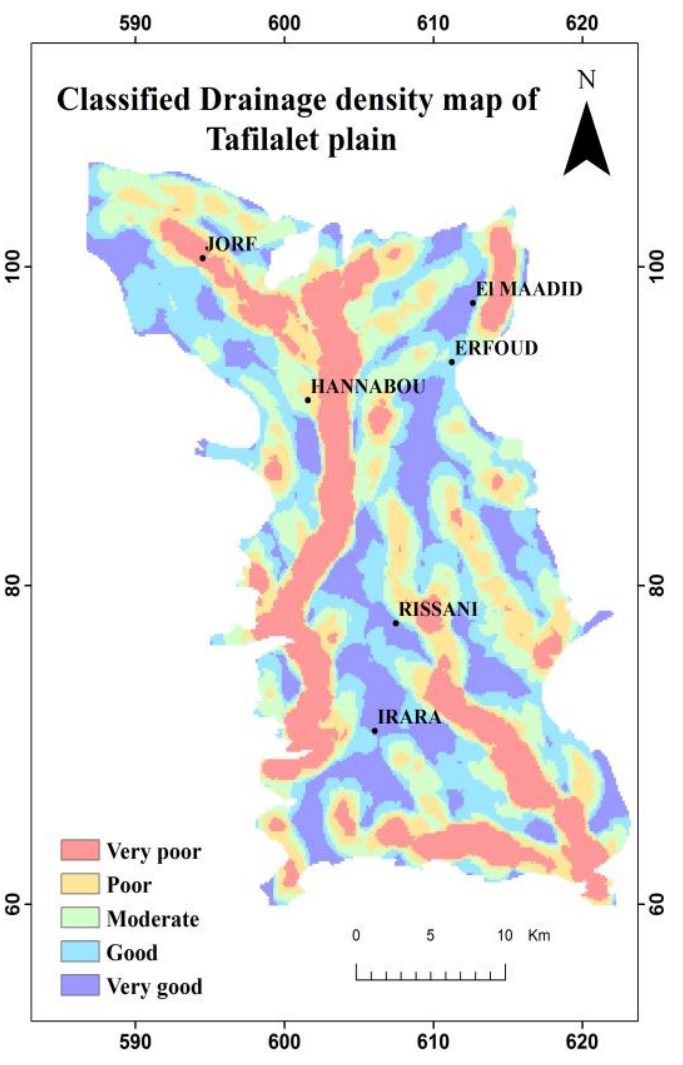

Figure 4: (Continued) 
Table 2: Classes of each parameter and assigned categories

\begin{tabular}{|l|l|l|c|}
\hline Parameter & Class & Category & Score \\
\hline Slope $(\%)$ & $0-3$ & Very good & 9 \\
& $3-6$ & Good & 8 \\
& $6-9$ & Moderate & 5 \\
& $9-15$ & Poor & 2 \\
& $>15$ & Very poor & 1 \\
\hline Soil & Calcisols & Very good & 9 \\
& Fluvisols & Good & 8 \\
& Leptosol & Moderate & 5 \\
\hline Geology & Primary & Very poor & 1 \\
& Early quaternary (Regs, crusts) & Moderate & 5 \\
& Early quaternary (Puddingstone, Lake Limestone, Sandstone) & Good & 8 \\
& Late quaternary & Very good & 9 \\
\hline LCLU & Sand & Very good & 9 \\
& Vegetation & Good & 8 \\
& Buildings & Very poor & 1 \\
& Bare ground & Poor & 2 \\
\hline Depth to the water table $(\mathrm{m})$ & $2-5$ & Very poor & 1 \\
& $5-10$ & Poor & 2 \\
& $10-20$ & Moderate & 5 \\
& $20-30$ & Good & 8 \\
& $>30$ & Very good & 9 \\
\hline Transmissivity $\left(\mathrm{m}^{2} / \mathrm{s}\right)$ & $0.00004-0.005$ & Very poor & 1 \\
& $0.005-0.015$ & Poor & 2 \\
& $0.015-0.025$ & Moderate & 5 \\
& $0.025-0.05$ & Good & 8 \\
& $>0.05$ & Very good & 9 \\
\hline Electrical conductivity $(\mu \mathrm{s} / \mathrm{cm})$ & $880-1000$ & Very good & 9 \\
& $1000-5000$ & Good & 8 \\
& $5000-10000$ & Moderate & 5 \\
& $10000-30000$ & Poor & 2 \\
& $>30000$ & Very poor & 1 \\
\hline Drainage density $\left(\mathrm{km} / \mathrm{km}^{2}\right)$ & $0-1$ & Very good & 9 \\
& $1-2$ & Good & 8 \\
& $2-3$ & Moderate & 5 \\
& $3-4$ & Poor & 2 \\
& $>4$ & Very poor & 1 \\
\hline
\end{tabular}

After structuring the problem in such a way, the second step is to evaluate, compare and prioritize in a pairwise comparison matrix, based on decision-makers' judgments each criterion against the others pertaining to their importance in the problem decision making. To represent the magnitude of judgments, Saaty's fundamental scale should be used (Table 4), in doing so, relative weights of each criterion is deduced using Saaty's eigenvector technique and the generated weights must be validated because judgments are subjective and can typically be made with errors, so Saaty defined an index for measuring the degree of inconsistency which is the consistency ratio C. R. and it should be computed.

Table 3: Adopted evaluation scale for reclassification

\begin{tabular}{|l|c|c|c|c|c|}
\hline Category & $\begin{array}{c}\text { Very } \\
\text { poor }\end{array}$ & Poor & Moderate & Good & $\begin{array}{c}\text { Very } \\
\text { good }\end{array}$ \\
\hline Score & 1 & 2 & 5 & 8 & 9 \\
\hline
\end{tabular}

Actually, C. R. is a way of measuring the number of "errors" created when making the judgments, the rule-of-thumb is that if the C.R. is below 0.1 , the errors are relatively small, thus the final estimate is acceptable [70,72-76].

The above-explained concept of AHP could be explained mathematically as follows:

Suppose $c_{1}, c_{2}, \ldots, c_{n}$ are $n$ criteria influencing a decision with respect to a given problem, the pairwise comparisons matrix $B=\left[b_{i j}\right]$ of that problem is an $n \times n$ matrix and it may be represented as follows :

$$
\begin{aligned}
& \begin{array}{llll}
c_{1} & \ldots & c_{n}
\end{array} \\
& \begin{array}{c}
c_{1} \\
\vdots \\
c_{n}
\end{array}\left[\begin{array}{ccc}
1 & \cdots & b_{1 n} \\
\vdots & \ddots & \vdots \\
1 / b_{1 n} & \cdots & 1
\end{array}\right]
\end{aligned}
$$

comparing the $\mathrm{n}$ criteria in pairs should comply with the following conditions: 
$b_{i j}>0$ and $b_{i j}=\frac{1}{b_{j i}}$ for all $i$ and $j$ which means that $B$ should be a positive and a reciprocal matrix. Besides, the values that can be attributed to $b_{i j}$ for all $i$ and $j$ must be on the scale of intensities defined by Saaty (Table 4).

Table 4: The fundamental Scale

\begin{tabular}{|l|l|l|}
\hline $\begin{array}{l}\text { Intensity of } \\
\text { importance }\end{array}$ & Definition & Explanation \\
\hline 1 & Equal importance & $\begin{array}{l}\text { Two criteria } \\
\text { contribute } \\
\text { equally to the } \\
\text { objective }\end{array}$ \\
\hline 3 & Moderate importance & $\begin{array}{l}\text { one criterion is } \\
\text { slightly favored } \\
\text { over another }\end{array}$ \\
\hline 5 & Strong importance & $\begin{array}{l}\text { one criterion is } \\
\text { strongly favored } \\
\text { over another }\end{array}$ \\
\hline 7 & $\begin{array}{l}\text { Very strong importance } \\
\text { one criterion is } \\
\text { highly favored } \\
\text { over another }\end{array}$ \\
\hline 9 & $\begin{array}{l}\text { Extreme importance } \\
\text { oneriterion is } \\
\text { extremely } \\
\text { favored over } \\
\text { another }\end{array}$ \\
\hline $2,4,6,8$ & $\begin{array}{l}\text { Intermediate values } \\
\text { above values assigned to it } j \text { has the reciprocal } \\
\text { value when compared with } i .\end{array}$ & $\begin{array}{l}\text { when } \\
\text { compromise is } \\
\text { needed }\end{array}$ \\
\hline Reciprocals
\end{tabular}

Deriving the weights $w_{1}, w_{2}, \ldots, w_{n}$ relative to the $n$ criteria $c_{1}$, $c_{2}, \ldots, c_{n}$ can be done by Saaty's eigenvector technique when judgments are inconsistent. Saaty's eigenvector technique stipulate that weights can be computed as the principal right eigenvector of the matrix $B$ :

$$
B W=\lambda_{\max } W
$$

where $\lambda_{\max }$ is the maximum eigenvalue of the matrix $B$, or

$$
w_{i}=\frac{\sum_{j=1}^{n} b_{i j} w_{j}}{\lambda_{\max }} \text { for all } i=1,2, \ldots, n
$$

After generating the weights, the consistency of the matrix should be measured by C.R. as explained above but first consistency index C.I. should be computed by the following formula:

$$
C . I=\frac{\lambda_{\max }-n}{n-1}
$$

because C.R. is the ratio of C.I. to R.I. :

$$
C . R=\frac{C . I}{R . I}
$$

with:

R.I. is the random index and is defined for each size of the matrix which is illustrated in Table 5.

C.R. must be less than 0.1 to consider the result as acceptable, larger values require the decision-maker to revise judgments in order to reduce the inconsistencies.

Therefore, for the current study, application of the AHP gives firstly the hierarchy structure illustrated in Figure 5, secondly, the pairwise matrix (Table 6) was developed by comparing pairs of factors with the help of expert point of views and using the fundamental scale of Saaty (Table 4) to translate judgments into values. Comparisons were done with regard to the relative influence of each factor on aquifer recharge and on implementing the (AAR) technique in Tafilalet plain. R.I. used is 1.41 because the dimension of the pairwise matrix of the current study is $8 \times 8$ (Table 6) so, after computation, the obtained C.R. is equal to 0.041 which is less than 0.1 and according to the AHP method this result is satisfactory and the generated weights are acceptable.

Based on the generated weights, geology is the highest eigenvector while drainage density is the lowest (Table 6). In fact, geology, soil type, depth to the water table, and transmissivity are the factors that were given the highest weights. This was expected because, according to the analysis that was made during pairwise comparisons, the first thing to look out for in a project for artificial recharge of an aquifer suffering from overexploitation is the geological formations, which must be sufficiently permeable and transmissive, the soil, which must have a high infiltration capacity and the groundwater which must be deep enough to provide sufficient space for water storage to allow the water table to regenerate its level.

\subsection{AAR index generation}

After generating the relative weights for each factor by the AHP method, the reclassified thematic layers of the factors were multiplied by their weights and finally added up using the weighted sum function of ArcGIS software.

Thus, the potential sites for the artificial aquifer recharge map was produced by calculating the AAR index according to the following formula:

$$
I_{A A R}=\sum_{i=1}^{n} F_{i} w_{i}
$$

where:

$-I_{A A R}$ is the AAR index

$-n$ is the number of factors influencing (AAR) which is eight in the current study

$-F_{i}$ stands for factor

$-w_{i}$ stands for weight

Table 5: Random inconsistency index

\begin{tabular}{|l|l|l|l|l|l|l|l|l|l|l|}
\hline$n$ & 1 & 2 & 3 & 4 & 5 & 6 & 7 & 8 & 9 & 10 \\
\hline R.I. & 0.00 & 0.00 & 0.58 & 0.90 & 1.12 & 1.24 & 1.32 & 1.41 & 1.45 & 1.49 \\
\hline
\end{tabular}




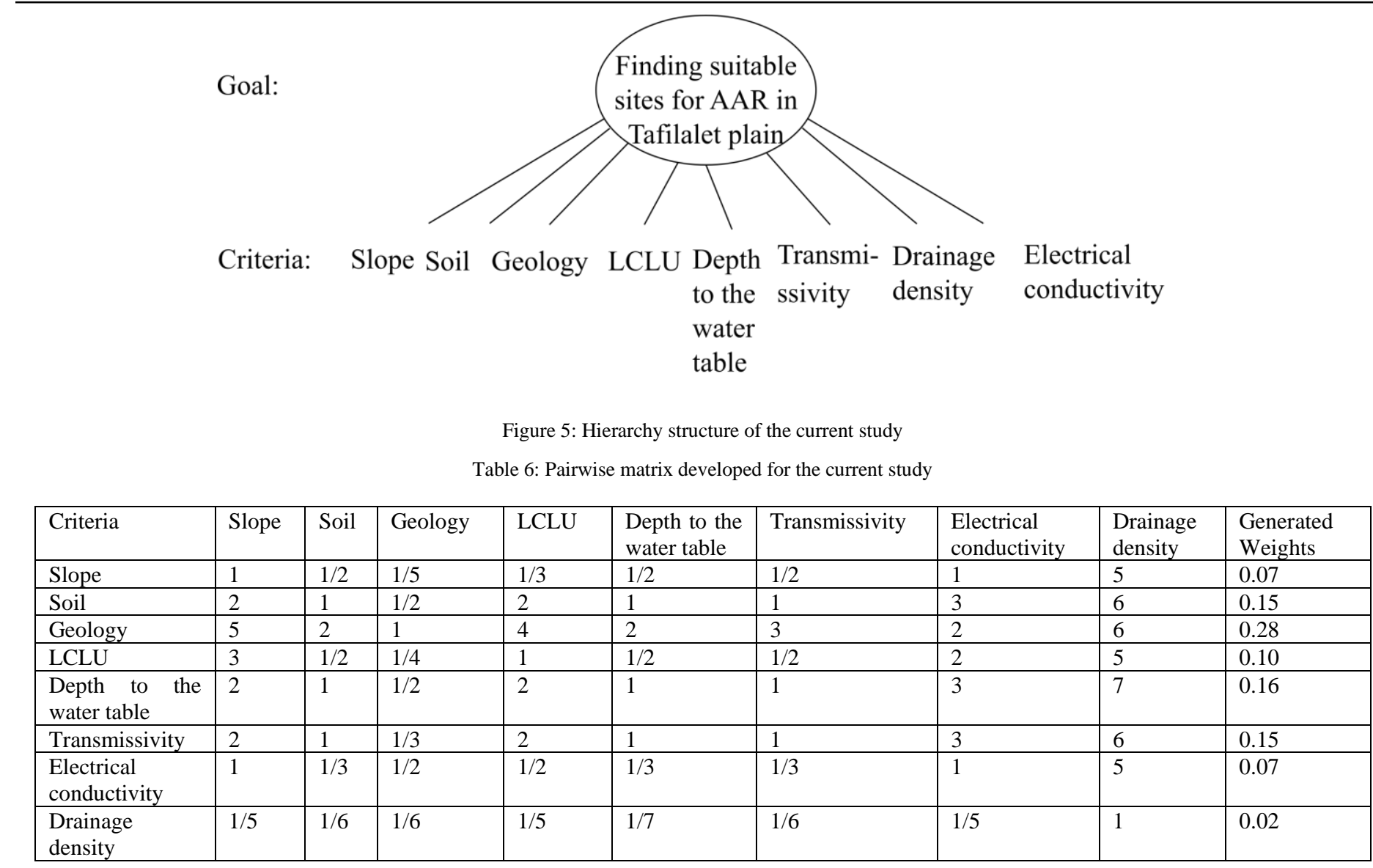

\section{Result}

The map of potential sites for artificial aquifer recharge which is illustrated in Figure 6 was produced as explained above and then reclassified according to five categories which are: very poorly suitable, poorly suitable, moderately suitable, suitable, and very suitable. It indicates that the most suitable areas for the artificial groundwater recharge of Tafilalet aquifer are located notably in the northeast and in the west of the plain. Statistically, About $47 \%$ of the study area is suitable for artificial aquifer recharge and about $40 \%$ are moderately suitable. Thus, those results can be used to formulate an efficient groundwater management plan for sustainable utilization of these limited resources because identified areas will be prioritized in the implementation of artificial aquifer recharge projects.

Based on the produced map of potential sites for artificial recharge of Tafilalet aquifer (Figure 6), most suitable zones are underlain by high permeable geological formations that mostly belong to the late quaternary and covered with soils with high infiltration capacity most often constituted by alluvium and basic aeolian reliefs rich in meteoric materials and located in areas where the water table is very deep more than $20 \mathrm{~m}$ deep in addition the slope of the plain is generally not too steep and the abovementioned description of the Tafilalet aquifer revealed that it is an alluvial and unconfined aquifer so, the artificial aquifer recharge technique most conducive with regard to the aforementioned conditions is infiltration basins nevertheless, the climatic characteristics of the region known by very high evapotranspiration rates will constitute a big challenge because more water will be lost by evaporation so less water will infiltrate unless the artificial aquifer recharge is conducted just during wet seasons when evapotranspiration rate decreases. Thus, several other factors must be taken into account when deciding whether a specific (AAR) system is suitable to be implemented, even if the appropriate locations are identified.

\section{Discussion}

The present-day situation of Tafilalet aquifer should urge water managers to work hard to avoid its worsening so, great efforts in risk mitigation need to be greatly accelerated and they should be centered on a range of scientific and engineering-based solutions. The current study presents one of those solutions which is the (AAR) and how to identify, in a scientific way, the most suitable locations for its implementation. In fact, A GIS-based multicriteria analysis was performed, using eight thematic maps in order to produce an appropriate map for the identification of sites for (AAR) in Tafilalet plain. The resulting map shows that the most suitable areas are identified in the northeast and in the west of the region while inappropriate locations are limited to small portions in the northern, southern, and eastern parts of the study area. This result is extremely important because it will help taking appropriate decisions for mitigating the overexploitation problem of the Tafilalet aquifer that is why the scientific approach should be taken into consideration in such important projects because it gives nearly accurate results and it brings time savings. 


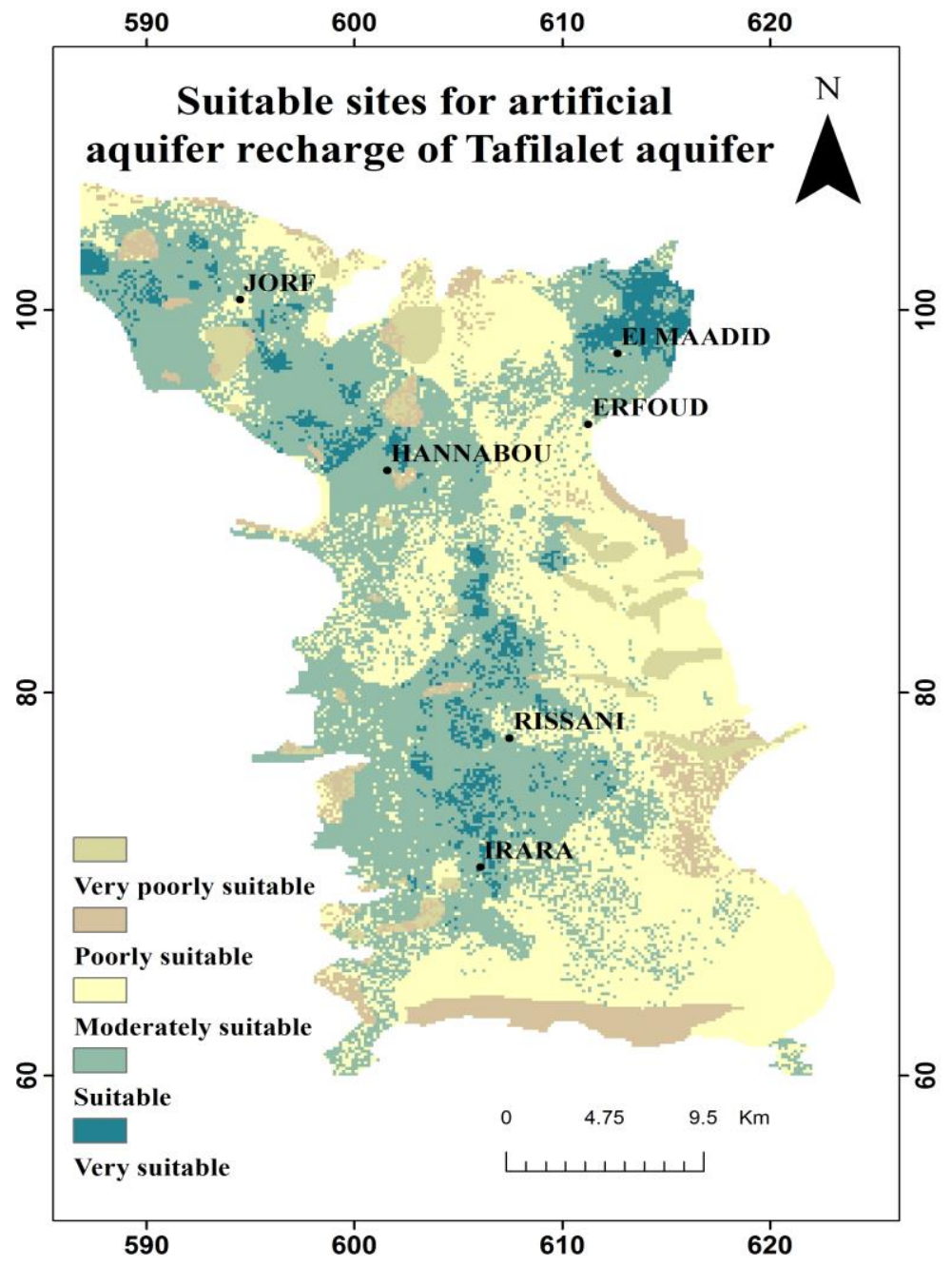

Figure 6: Potential artificial aquifer recharge sites map

The (AAR) will certainly sort out the problem of depletion of groundwaters in the Tafilalet aquifer as it was proved in some other aquifers in Morocco and in other countries. In fact, the (AAR) has already initiated and applied to some aquifers suffering from the same problem in Morocco such as the Charf El Akab aquifer in the region of Tangier, the Haouz Mejjate aquifer in the region of Marrakech, the Souss aquifer in the region of Agadir and the Berrechid aquifer located in the south of Casablanca, those aquifers have already started to reap its benefits. Even if the (AAR) practices in Morocco are still very much in their infancy, the technology is beginning to be recognized at the national level as having a value in tackling groundwater depletion issues.

Some attempts have been made in Tafilalet plain by the hydraulic basin agency of Guir-Ziz-Rheris in this regard and artificial recharging techniques have already begun to emerge on the plain, such as the construction of dikes or sills in the bed of the wadi Ziz in order to slow down the speed of the water and increase the wetted areas along the bed of the wadi, however, if the working field is extended to other locations that must be well chosen, these locations must be identified by means of scientific decisionmaking like GIS and multi-criteria analysis taking into consideration several criteria such as geological, pedological, hydrogeological, and many other factors to make sure that they are suitable for artificial recharge, in doing so, other artificial recharge techniques can be performed and can better and quickly restore the groundwater level situation of Tafilalet aquifer to its normal stage.

\section{Conclusion}

The aridity of the climate together with the excessive need for water is putting pressure on groundwater resources of Tafilalet plain so, the water level of the Tafilalet aquifer is declining to a threateningly low level which may undermine its productivity and causing its depletion, problems which are more likely to have irreversible adverse effects may occur like imperiling groundwater-dependent ecosystems, human activities as well as economic development of the region. Thus, the core objective of this study is to investigate suitable places for artificially recharge the Tafilalet aquifer to restore its levels to normal and fill the gap caused by overexploitation. For this purpose, thematic layers of factors that control groundwater recharge like depth to the water table, drainage density, electrical conductivity, slope, aquifer transmissivity, geology, soil, LCLU were prepared mapped, and reclassified in a GIS (ArcGIS software), after that, AHP method 
was applied to compute weights of each factor and the map of appropriate sites of artificial groundwater recharge was generated by the application of weighted sum tool of ArcGIS software. The result has revealed that around $47 \%$ of the study area has been identified as a high potential zone for groundwater recharge which is a very important outcoming. However, identifying suitable places is essential but not sufficient for implementing (AAR) because as mentioned above even if infiltration basins are estimated as the appropriate (AAR) system to implement in Tafilalet plain, there are other factors to consider like climatic conditions of the region, need for periodic maintenance of the basin in order to sustain infiltration rates over the long term because organic matter build-up, silting and/or clogging can make the surface of the basin impervious and the capacity of infiltration will decrease over time in addition to the existence of a good quality water source nearby that will ensure the supply of water to be put into the basin and many other conditions that if not met will render the project impractical. Lastly, the present study has shown an example of the benefits of coupling multi-criteria analysis with GIS and remote sensing techniques in taking relevant decisions to better manage and protect groundwater resources.

\section{Conflict of Interest}

The authors declare no conflict of interest.

\section{Acknowledgment}

The authors wish to record their deep sense of gratitude and profound thanks to all the employees of hydraulic basin agency of Guir-Ziz-Rheris for their warm welcome and their support to bring this work to fruition.

\section{References}

[1] I.A. Shiklomanov, "World water resources: a new appraisal and assessment for the 21 st century; $1998, " 40,1998$

[2] Gleick Peter H, World fresh water resources, 1993.

[3] T. Oki, Shinjiro. Kanae, "Global Hydrological Cycles and World Water Resources," Science, 313(5790), 1068-1072, 2006, doi:10.1126/science.1128845.

[4] S. Tushaar, Burke J, Villholth K, Angelica, M, Custodio, E, Daibes, F, Hoogesteger, J, Giordano, Mark, Girman, J, van der Gun, J, Kendy, E, Kijne, J, Llamas, R, Masiyandima, Mutsa, Margat, J, Marin, L, Peck, J, Rozelle, S, Sharma, Bharat R, Vincent, L, Wang, J, Groundwater: a global assessment of scale and significance, 395-423., 2007.

[5] S. Siebert, V. Henrich, K. Frenken, J. Burke, Update of the digital global map of irrigation areas to version 5., Institute of Crop Science and Resource Conservation, University of Bonn, Germany; Land and Water Division, Food and Agriculture Organization of the United Nations, Rome, Italy, 2013, doi:10.13140/2.1.2660.6728.

[6] T. Havril, Á. Tóth, J.W. Molson, A. Galsa, J. Mádl-Szönyi, "Impacts of predicted climate change on groundwater flow systems: Can wetlands disappear due to recharge reduction?," Journal of Hydrology, 563, 11691180, 2018, doi:10.1016/j.jhydrol.2017.09.020.

[7] E. Sener, A. Davraz, "Assessment of groundwater vulnerability based on a modified DRASTIC model, GIS and an analytic hierarchy process (AHP) method: the case of Egirdir Lake basin (Isparta, Turkey)," Hydrogeology Journal, 21(3), 701-714, 2013, doi:10.1007/s10040-012-0947-y.

[8] M. Giordano, "Global Groundwater? Issues and Solutions," Annual Review of Environment and Resources, 34(1), 153-178, 2009, doi:10.1146/annurev.environ.030308.100251.

[9] A.S. Qureshi, P.G. McCornick, A. Sarwar, B.R. Sharma, "Challenges and Prospects of Sustainable Groundwater Management in the Indus Basin, Pakistan," Water Resources Management, 24(8), 1551-1569, 2010, doi:10.1007/s11269-009-9513-3.

[10] A. Jódar-Abellán, J.A. Albaladejo-García, D. Prats-Rico, "ARTIFICIAL GROUNDWATER RECHARGE. REVIEW OF THE CURRENT
KNOWLEDGE OF THE TECHNIQUE,” 12, 2017.

[11] S. Kaliraj, N. Chandrasekar, N.S. Magesh, "Identification of potential groundwater recharge zones in Vaigai upper basin, Tamil Nadu, using GISbased analytical hierarchical process (AHP) technique," Arabian Journal of Geosciences, 7(4), 1385-1401, 2014, doi:10.1007/s12517-013-0849-x.

[12] P.K. Naik, M. Mojica, F. Ahmed, S. Al-Mannai, "Storm water injection in Bahrain: pilot studies," Arabian Journal of Geosciences, 10(20), 2017, doi:10.1007/s12517-017-3232-5.

[13] A. Rawluk, A. Curtis, E. Sharp, B.F.J. Kelly, A.J. Jakeman, A. Ross, M. Arshad, R. Brodie, C.A. Pollino, D. Sinclair, B. Croke, M.E. Qureshi, "Managed aquifer recharge in farming landscapes using large floods: an opportunity to improve outcomes for the Murray-Darling Basin?," Australasian Journal of Environmental Management, 20(1), 34-48, 2013, doi:10.1080/14486563.2012.724785.

[14] L.F. Konikow, E. Kendy, "Groundwater depletion: A global problem," Hydrogeology Journal, 13(1), 317-320, 2005, doi:10.1007/s10040-0040411-8.

[15] M. Giordano, K.G. Villholth, eds., The agricultural groundwater revolution: opportunities and threats to development, CABI, Wallingford, 2007.

[16] D. Molden, al, eds., Water for food, water for life: a comprehensive assessment of water management in agriculture, Earthscan, 2007.

[17] M.I. Al-Hamdi, Competition for scarce groundwater in the Sana'a Plain, Yemen: a study on the incentive systems for urban and agricultural water use, CRC Press / Balkema, Netherlands, 2000.

[18] Yoshihide Wada, Ludovicus P. H. van Beek, Cheryl M. van Kempen, Josef W. T. M. Reckman, Slavek Vasak, Marc F. P. Bierkens, "Global depletion of groundwater resources," GEOPHYSICAL RESEARCH LETTERS, 37, 2010.

[19] F. Pedrero, A. Albuquerque, H. Marecos do Monte, V. Cavaleiro, J.J. Alarcón, "Application of GIS-based multi-criteria analysis for site selection of aquifer recharge with reclaimed water," Resources, Conservation and Recycling, 56(1), 105-116, 2011, doi:10.1016/j.resconrec.2011.08.003.

[20] A.S. Qureshi, P.G. McCornick, M. Qadir, Z. Aslam, "Managing salinity and waterlogging in the Indus Basin of Pakistan," Agricultural Water Management, 95(1), 1-10, 2008, doi:10.1016/j.agwat.2007.09.014.

[21] N. Iqbal, F. Hossain, H. Lee, G. Akhter, "Satellite Gravimetric Estimation of Groundwater Storage Variations Over Indus Basin in Pakistan," IEEE Journal of Selected Topics in Applied Earth Observations and Remote Sensing, 9(8), 3524-3534, 2016, doi:10.1109/JSTARS.2016.2574378.

[22] P. Pavelic, K. Srisuk, P. Saraphirom, S. Nadee, K. Pholkern, S. Chusanathas, S. Munyou, T. Tangsutthinon, T. Intarasut, V. Smakhtin, "Balancing-out floods and droughts: Opportunities to utilize floodwater harvesting and groundwater storage for agricultural development in Thailand," Journal of Hydrology, 55-64, 2012, doi:10.1016/j.jhydrol.2012.08.007.

[23] W. Martín-Rosales, J. Gisbert, A. Pulido-Bosch, A. Vallejos, A. FernándezCortés, "Estimating groundwater recharge induced by engineering systems in a semiarid area (southeastern Spain)," Environmental Geology, 52(5), 985-995, 2007, doi:10.1007/s00254-006-0541-5.

[24] Y.B. Katpatal, A.M. Pophare, B.R. Lamsoge, "A groundwater flow model for overexploited basaltic aquifer and Bazada formation in India," Environmental Earth Sciences, 72(11), 4413-4425, 2014 doi:10.1007/s12665-014-3342-2.

[25] A. Singh, S.N. Panda, K.S. Kumar, C.S. Sharma, "Artificial Groundwater Recharge Zones Mapping Using Remote Sensing and GIS: A Case Study in Indian Punjab," Environmental Management, 52(1), 61-71, 2013, doi:10.1007/s00267-013-0101-1.

[26] Y.S. Prasad, B.V. Rao, "Groundwater depletion and groundwater balance studies of Kandivalasa River Sub Basin, Vizianagaram District, Andhra Pradesh, India," Groundwater for Sustainable Development, 6, 71-78, 2018, doi:10.1016/j.gsd.2017.11.003.

[27] C.J. Nevill, "Managing Cumulative Impacts: Groundwater Reform in the Murray-Darling Basin, Australia," Water Resources Management, 23(13), 2605-2631, 2009, doi:10.1007/s11269-009-9399-0.

[28] L.J. Frookh, L. Froukh, "Artificial Aquifer Recharge with Treated Wastewater in North Gaza," Riyadh,Saudi Arabia: 9, 2019.

[29] R. Spandre, Artificial Groundwater Recharge, EOLSS: 20, 2009.

[30] D. Das, Drainage and lineament analysis towards artificial recharge of groundwater, Springer Berlin Heidelberg, Berlin, Heidelberg: 37-44, 2011, doi:10.1007/978-3-642-24076-8_5.

[31] K.G. Villholth, E. Lopez-gunn, J. Van Der Gun, A. Garrido, K. Conti, Advances in Groundwater Governance, CRC Press, 2019.

[32] M.R. Llamas, P. Martínez-Santos, "Intensive Groundwater Use: Silent Revolution and Potential Source of Social Conflicts," Journal of Water Resources Planning and Management, 131(5), 337-341, 2005, doi:10.1061/(ASCE)0733-9496(2005)131:5(337). 
[33] S.B. Gingerich, C.I. Voss, A.G. Johnson, "Seawater-flooding events and impact on freshwater lenses of low-lying islands: Controlling factors, basic management and mitigation," Journal of Hydrology, 551, 676-688, 2017, doi:10.1016/j.jhydrol.2017.03.001.

[34] W.-C. Hung, C. Hwang, J.-C. Liou, Y.-S. Lin, H.-L. Yang, "Modeling aquifer-system compaction and predicting land subsidence in central Taiwan," Engineering Geology, 147-148, 78-90, 2012, doi:10.1016/j.enggeo.2012.07.018.

[35] T.J. Burbey, "The Influence of Geologic Structures on Deformation due to Ground Water Withdrawal," Ground Water, 46(2), 202-211, 2008, doi:10.1111/j.1745-6584.2007.00395.x.

[36] Q. Feng, G. Liu, L. Meng, E. Fu, H. Zhang, K. Zhang, "Land subsidence induced by groundwater extraction and building damage level assessment a case study of Datun, China," Journal of China University of Mining and Technology, 18(4), 556-560, 2008, doi:10.1016/S1006-1266(08)60293-X.

[37] M.J. Abdulrazzak, P.D. Oikonomou, N.S. Grigg, "Transboundary Groundwater Cooperation among Countries of the Arabian Peninsula," Journal of Water Resources Planning and Management, 146(1), 05019023, 2020, doi:10.1061/(ASCE)WR.1943-5452.0001140.

[38] R.L. Nelson, "Assessing local planning to control groundwater depletion: California as a microcosm of global issues: LOCAL PLANNING TO CONTROL GROUNDWATER DEPLETION," Water Resources Research, 48(1), 2012, doi:10.1029/2011WR010927.

[39] R.A. Freeze, J.A. Cherry, Groundwater, Prentice-Hall, Englewood Cliffs, N.J, 1979.

[40] E.A. Varouchakis, P.G. Theodoridou, G.P. Karatzas, "Decision-Making Tool for Groundwater Level Spatial Distribution and Risk Assessment Using Geostatistics in R," Journal of Hazardous, Toxic, and Radioactive Waste, 24(1), 04019031, 2020, doi:10.1061/(ASCE)HZ.2153-5515.0000464.

[41] C.K. Singh, Y.B. Katpatal, "A GIS Based Design of Groundwater Level Monitoring Network Using Multi-Criteria Analysis and Geostatistical Method," Water Resources Management, 31(13), 4149-4163, 2017, doi:10.1007/s11269-017-1737-z.

[42] W.B. Cutter, "Valuing Groundwater Recharge in an Urban Context," Land Economics, 83(2), 234-252, 2007.

[43] P. Dillon, "Future management of aquifer recharge," Hydrogeology Journal, 13(1), 313-316, 2005, doi:10.1007/s10040-004-0413-6.

[44] P. Dillon, P. Stuyfzand, T. Grischek, M. Lluria, R.D.G. Pyne, R.C. Jain, J. Bear, J. Schwarz, W. Wang, E. Fernandez, C. Stefan, M. Pettenati, J. van der Gun, C. Sprenger, G. Massmann, B.R. Scanlon, J. Xanke, P. Jokela, Y. Zheng, R. Rossetto, M. Shamrukh, P. Pavelic, E. Murray, A. Ross, J.P. Bonilla Valverde, A. Palma Nava, N. Ansems, K. Posavec, K. Ha, et al., "Sixty years of global progress in managed aquifer recharge," Hydrogeology Journal, 27(1), 1-30, 2019, doi:10.1007/s10040-018-1841-z.

[45] S. Rahimi, M. Shadman Roodposhti, R. Ali Abbaspour, "Using combined AHP-genetic algorithm in artificial groundwater recharge site selection of Gareh Bygone Plain, Iran,” Environmental Earth Sciences, 72(6), 19791992, 2014, doi:10.1007/s12665-014-3109-9.

[46] A.K. Bhattacharya, "ARTIFICIAL GROUND WATER RECHARGE WITH A SPECIAL REFERENCE TO INDIA," 8, 2010.

[47] T. Asano, Artificial Recharge of Groundwater, Butterworth Publishers, Boston, 1985.

[48] A. Mahdavi, S.H. Tabatabaei, M. Nouri, R. Mahdavi, "Identification of groundwater artificial recharge sites using Fuzzy logic: A case study of Shahrekord plain, Iran," 2012.

[49] H. Bouwer, "Artificial recharge of groundwater: hydrogeology and engineering," Hydrogeology Journal, 10(1), 121-142, 2002, doi:10.1007/s10040-001-0182-4.

[50] E. Widad, "Etude de la zone favorable pour la recharge artificielle de la nappe phréatique Mnasra," 55, 2014.

[51] H. Nasiri, A.D. Boloorani, H.A.F. Sabokbar, H.R. Jafari, M. Hamzeh, Y. Rafii, "Determining the most suitable areas for artificial groundwater recharge via an integrated PROMETHEE II-AHP method in GIS environment (case study: Garabaygan Basin, Iran)," Environmental Monitoring and Assessment, 185(1), 707-718, 2013, doi:10.1007/s10661012-2586-0.

[52] H.A. Faraji Sabokbar, H. Nasiri, M. Hamze, S. Talebi, Y. Rafiei, "Identification of suitable areas for artificial groundwater recharge using integrated ANP and pair wise comparison methods in GIS environment, (case study: Garbaygan Plain of Fasa)," Geography and Environmental Planning, 44(4), 2012.

[53] J. Ghayoumian, B. Ghermezcheshme, S. Feiznia, A.A. Noroozi, "Integrating GIS and DSS for identification of suitable areas for artificial recharge, case study Meimeh Basin, Isfahan, Iran,” Environmental Geology, 47(4), 493500, 2005, doi:10.1007/s00254-004-1169-y.
[54] I. Bouaamlat, A. Larabi, M. Faouzi, "Assessment of Water Resources in the Tafilalet Oasis System by a Mathematical Model (South East of Morocco)," $1,2012$.

[55] I.P. Senanayake, D.M.D.O.K. Dissanayake, B.B. Mayadunna, W.L. Weerasekera, "An approach to delineate groundwater recharge potential sites in Ambalantota, Sri Lanka using GIS techniques," Geoscience Frontiers, 7(1), 115-124, 2016, doi:10.1016/j.gsf.2015.03.002.

[56] J. Ghayoumian, M. Mohseni Saravi, S. Feiznia, B. Nouri, A. Malekian, "Application of GIS techniques to determine areas most suitable for artificial groundwater recharge in a coastal aquifer in southern Iran," Journal of Asian Earth Sciences, 30(2), 364-374, 2007, doi:10.1016/j.jseaes.2006.11.002.

[57] A. Chowdhury, M.K. Jha, V.M. Chowdary, "Delineation of groundwater recharge zones and identification of artificial recharge sites in West Medinipur district, West Bengal, using RS, GIS and MCDM techniques," Environmental Earth Sciences, 59(6), 1209-1222, 2010, doi:10.1007/s12665-009-0110-9.

[58] C. william Carlston, Drainage density and streamflow, Professional Paper, 1963.

[59] Guide on artificial recharge to groundwater, central ground water board ministry of water resources, new delhi, 2000.

[60] Z. Şen, Basic Porous Medium Concepts, Elsevier: 43-97, 2015, doi:10.1016/B978-0-12-800075-5.00002-9.

[61] J. Bear, Hydraulics of groundwater, McGraw-Hill, Inc., New York, 1979.

[62] G.P. Kruseman, N.A. de Ridder, Analysis and evaluation of pumping test data, 2. ed. (compl. rev.), repr, International Institute for Land Reclamation and Improvement, Wageningen, 1994.

[63] W. Luo, D.T. Pederson, "Hydraulic conductivity of the High Plains Aquifer re-evaluated using surface drainage patterns: HYDRAULIC CONDCTIVITY RE-EVALUATED," Geophysical Research Letters, 39(2), n/a-n/a, 2012, doi:10.1029/2011GL050200.

[64] J.J. De Vries, "The groundwater outcrop-erosion model; evolution of the stream network in The Netherlands," Journal of Hydrology, 29(1-2), 43-50, 1976, doi:10.1016/0022-1694(76)90004-4.

[65] R.E. Horton, "EROSIONAL DEVELOPMENT OF STREAMS AND THEIR DRAINAGE BASINS; HYDROPHYSICAL APPROACH TO QUANTITATIVE MORPHOLOGY," Geological Society of America Bulletin, 56(3), 275, 1945, doi:10.1130/00167606(1945)56[275:EDOSAT]2.0.CO;2.

[66] J. Krishnamurthy, A. Mani, V. Jayaraman, M. Manivel, "Groundwater resources development in hard rock terrain - an approach using remote sensing and GIS techniques," International Journal of Applied Earth Observation and Geoinformation, 2(3-4), 204-215, 2000, doi:10.1016/S0303-2434(00)85015-1.

[67] B. Rambert, Recherche sur la signification hydrogéologique de la densité du drainage: Application à la détermination et à la cartographie de l'écoulemment souterrain., Bureau de recherche géologique et minières, France, 1973.

[68] T. Dunne, Chapter 1. Hydrology mechanics, and geomorphic implications of erosion by subsurface flow, Geological Society of America: 1-28, 1990, doi:10.1130/SPE252-p1.

[69] J.A. Sandoval, C.L. Tiburan, "Identification of potential artificial groundwater recharge sites in Mount Makiling Forest Reserve, Philippines using GIS and Analytical Hierarchy Process," Applied Geography, 105, 73 85, 2019, doi:10.1016/j.apgeog.2019.01.010.

[70] B.L. Golden, E.A. Wasil, P.T. Harker, eds., The Analytic Hierarchy Process: Applications and Studies, Springer Berlin Heidelberg, Berlin, Heidelberg, 1989, doi:10.1007/978-3-642-50244-6.

[71] T.L. Saaty, "A scaling method for priorities in hierarchical structures," Journal of Mathematical Psychology, 15(3), 234-281, 1977 , doi:10.1016/0022-2496(77)90033-5.

[72] T.L. Saaty, "How to make a decision: The Analytic Hierarchy Process," European Journal of Operational Research, 48, 1990.

[73] R.W. Saaty, "The analytic hierarchy process - what it is and how it is used," Mathematical Modelling, 9(3-5), 161-176, 1987, doi:10.1016/02700255(87)90473-8.

[74] T.L. Saaty, "Decision making with the analytic hierarchy process," International Journal of Services Sciences, 1(1), 83, 2008, doi:10.1504/IJSSCI.2008.017590.

[75] E. Mu, M. Pereyra-Rojas, Understanding the Analytic Hierarchy Process, Springer International Publishing, Cham: 7-22, 2017, doi:10.1007/978-3319-33861-3_2.

[76] T.L. Saaty, What is the Analytic Hierarchy Process?, Springer Berlin Heidelberg, Berlin, Heidelberg: 109-121, 1988, doi:10.1007/978-3-64283555-1_5. 